\title{
Petrograpic and material observations of basaltic lapilli tuff, 1979 and 2017 Surtsey drill cores, Iceland
}

\author{
MARIE D. JACKSON ${ }^{1}$ \\ ${ }^{1}$ Department of Geology and Geophysics, University of Utah, Salt Lake City, Utah, U.S.A., m.d.jackson@utah.edu
}

\begin{abstract}
Petrographic studies of thin sections from the 1979 and 2017 Surtsey drill cores provide new insights into microstructural features in basaltic lapilli tuff sampled from the principal structural and hydrothermal zones of the volcano. These describe narrow rims of fine ash on altered glass pyroclasts in thin sections of the 2017 cores, characteristics of granular and microtubular structures in the original thin sections of the 1979 core, and glass alteration in diverse environments. The narrow ash rims follow the outlines of glass pyroclasts in the subaerial tuff cone and in submarine and sub-seafloor deposits; they suggest complex eruptive and depositional processes. The tubular microstructures resemble endolithic microborings in older oceanic basalt; they suggest possible microbial activity. Tubule lengths indicate rapid growth rates, up to $30 \mu \mathrm{m}$ in $\sim 15$ years. Comparisons of glass alteration in thin sections prepared immediately after drilling in 1979 and 2017 indicate differential time-lapse alteration processes in the structural and hydrothermal zones of the volcano. In contrast, thin sections of the 1979 core prepared after 38 years in the repository reveal labile glass alteration during archival storage. The oven-dry density of the sub-seafloor lapilli tuff decreases in 2017 samples with high porosity and water absorption and increases in 2017 samples with a compact ash matrix and lower water absorption. The petrographic descriptions and material measurements provide a foundational reference for further investigations of explosive eruption and deposition of basaltic tephra at Surtsey and the subsequent alteration of these deposits in the volcanic environment and, potentially, the curatorial environment.
\end{abstract}

\section{INTRODUCTION}

Explosive and effusive eruptions of basalt created the very young island of Surtsey from $1963-1967$ in the southernmost offshore extension of Iceland's southeastern volcanic zone (Thórarinsson et al. 1964, Thórarinsson 1965, 1967) (Fig. 1). Cored boreholes through the still hot volcano in 1979 and 2017 provide a precise time-lapse record of hydrothermal rock-water interactions and chemical, mineralogical, and physical change in the 50-year-old basaltic tephra and tuff. The 1979 drilling project at Surtsey produced a $181 \mathrm{~m}$ vertical core (SE-01) through Surtur, the eastern vent and tuff cone (Jakobsson \&
Moore 1982, 1986). The 2017 Surtsey Underwater volcanic System for Thermophiles, Alteration processes and INnovative Concretes (SUSTAIN) drilling project, sponsored by the International Continental Scientific Drilling Program, produced the adjacent vertical SE-02A and SE-02B cores and the inclined SE-03 core that probes the deeper structure of the volcano, as well as a subsurface observatory in the SE-02B borehole (Jackson et al. 2019a, Türke et al. 2019, Weisenberger et al. 2019). Studies of drill core samples and borehole fluids have provided new insights into the processes of explosive Surtseyan 


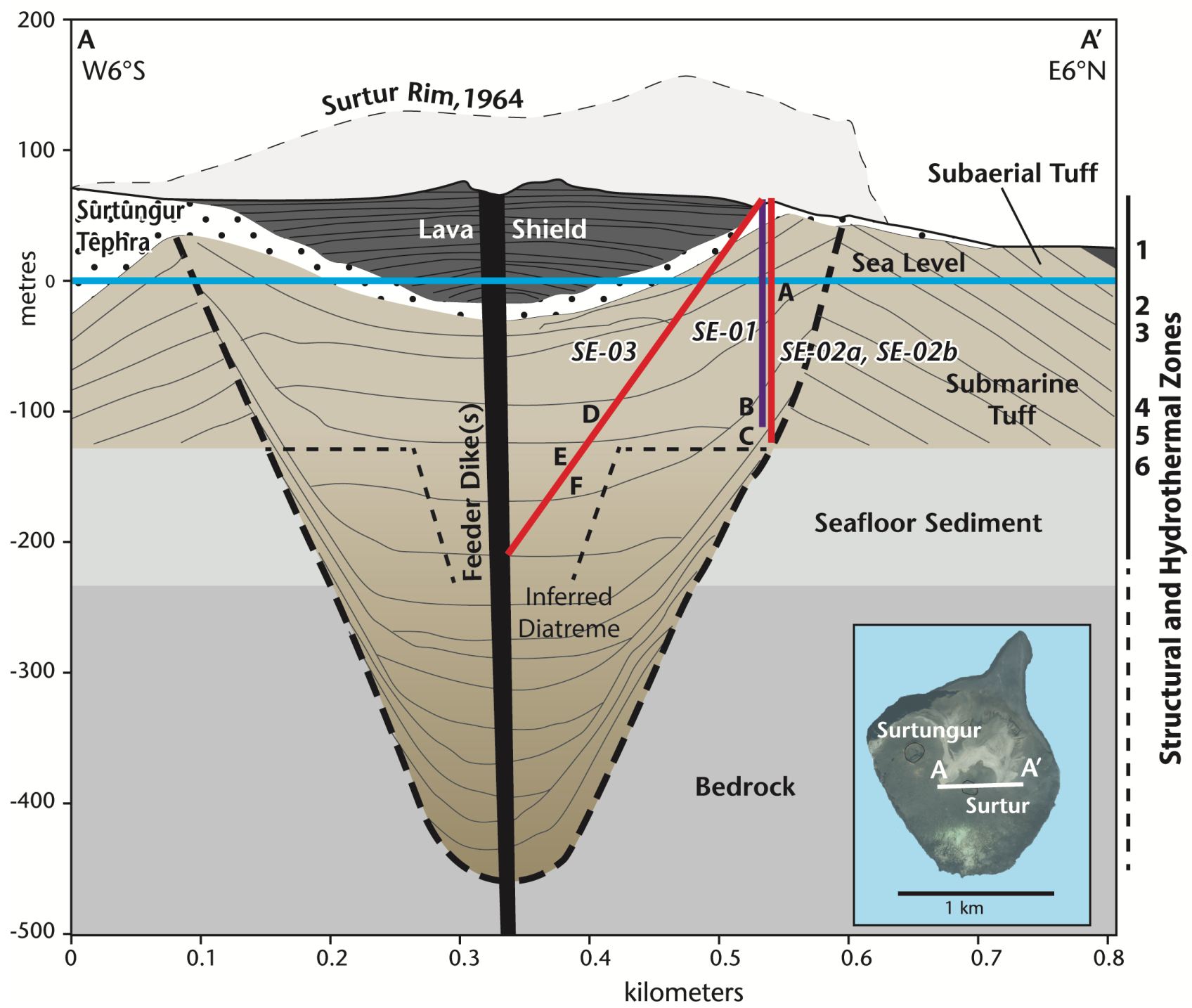

Figure 1. Interpretative, diagrammatic cross-section of Surtur, the eastern crater of Surtsey, showing eruptive deposits, seafloor sediments and sedimentary rocks, and a lava shield in the central crater (modified from Moore 1985, Jakobsson et al. 2009, Jackson et al. 2019a, Moore \& Jackson 2020). The heavy dashed line shows the sub-seafloor diatreme inferred by Moore (1985). The lighter dashed line shows the minimum subsurface vent and conduit deposits that will fit the 2017 drilling results (Jackson et al. 2019a). Layering orientations follow the geometrical analysis in Moore \& Jackson (2020). Petrographic studies (Figs. 2, 4, 6) describe features in 1979 and 2017 basaltic lapilli tuff drill core samples from (1) the subaerial tuff cone ( 0 - 58 m.b.s.), (2) the upper submarine tuff ( $58-85$ m.b.s.), (3) the maximal temperature zone ( 85 - 115 m.b.s.), (4) the submarine inflow zone (140 - 155 m.b.s.), (5) the lowermost borehole deposits above the pre-eruption seafloor (155 - 180 m.b.s.), and (6) the sub-seafloor tuff deposits (below 185 m.b.s.). A - F indicate examples of glass pyroclasts with ash rims in the submarine and sub-seafloor tuff (Fig. 2).

submarine and emergent volcanism, the palagonitic alteration of basaltic glass (sideromelane) in diverse fluid and temperature environments and associated changes in rock material characteristics, and the potential for rapid initiation of microbial activity in freshly erupted tephra (Jakobsson \& Moore 1982, 1986, Moore 1985, Marteinsson et al. 2015, Schipper et al. 2015, Jackson et al. 2019a, 2019b, Prause et al. 2020, McPhie et al. 2020, Moore \& Jackson 2020). Many aspects of these processes are currently under investigation. This article describes fine-scale features in thin sections of basaltic lapilli tuff from the 1979 and 2017 drill cores with petrographic microscopy. Changes in the density and water absorption characteristics of drill core samples are also recorded. The principal objective is to provide a reference for further investigations of the basaltic tephra at Surtsey and the subsequent alteration of these deposits under diverse environmental conditions. 

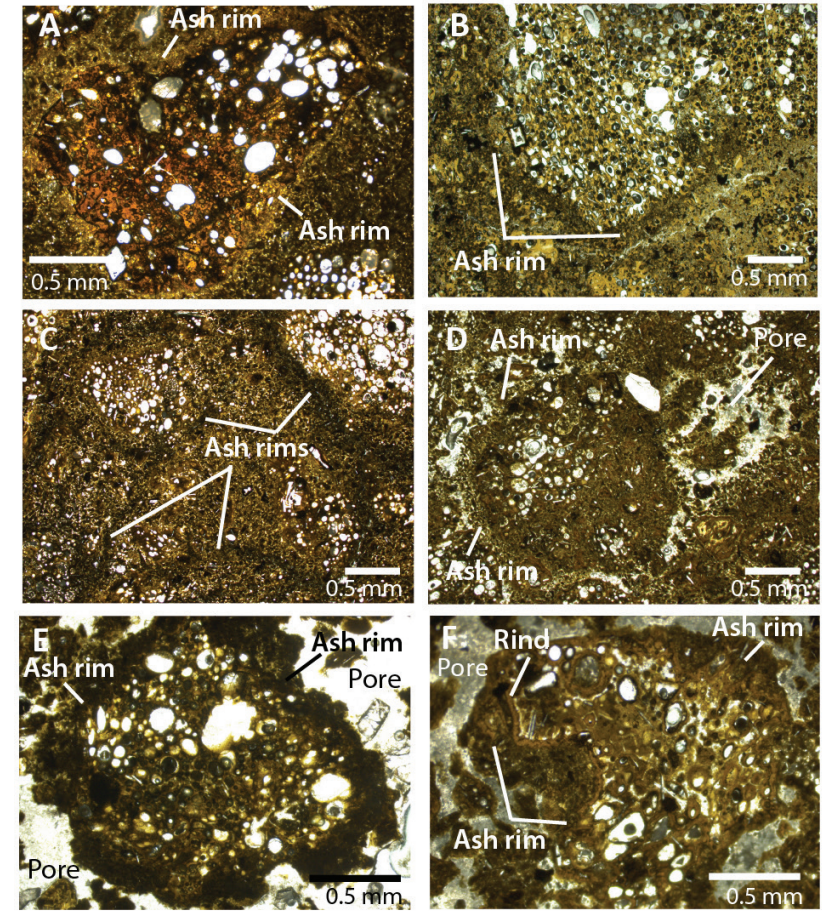

Figure 2. Petrographic images of coarse ash- and lapilli-sized particles with rims of fine ash in submarine and sub-seafloor lapilli tuff in 2017 Surtsey drill cores, plane polarized light (ppl) except (A). A) Near water level, 65.8 m.b.s., $110.3^{\circ} \mathrm{C}$ in $1980,102.8^{\circ} \mathrm{C}$ in 2017; highly altered glass particle with a rim of birefringent fine ash, SE-02B core, cross polarized light (xpl). B) Near the submarine inflow zone, 154.1 m.b.s., $83^{\circ} \mathrm{C}$ in $1980,82{ }^{\circ} \mathrm{C}$ in 2017 , SE-02B core; weakly altered glass lapillus with an opaque, nonbirefringent, altered fine ash rim. C) Lowermost submarine zone, 170 m.b.s., $68.6{ }^{\circ} \mathrm{C}$ in $1980,62.1^{\circ} \mathrm{C}$ in 2017 , SE-02B core; clot of weakly consolidated tephra agglomerations surrounded by fine, dark gray ash rims. D) Sub-seafloor lapilli tuff, 220.4 m measured depth, $58{ }^{\circ} \mathrm{C}$ post-drilling in 2017, SE-03 core (sample RS19); altered glass particle with a rim of angular fine ash, surrounded by narrow cavities partially filled with mineral cements. E) Subseafloor lapilli tuff, $258.9 \mathrm{~m}$ measured depth, $57{ }^{\circ} \mathrm{C}$ post-drilling in 2017, SE-03 core (sample RS24); altered glass particle with a dense rim of fine ash, surrounded by large, open cavities. F) Subseafloor lapilli tuff, $267.2 \mathrm{~m}$ measured depth, $57^{\circ} \mathrm{C}$ post-drilling in 2017, SE-03 core (sample RS25); altered glass particle with a thick rim of sub-angular coarse and fine ash, surrounded by large cavities filled with mineral cements. Temperature measurements from Jakobsson \& Moore (1982), Jackson et al. (2019a).

The petrographic studies first describe narrow rims of fine ash approximately $15-800 \mu \mathrm{m}$ in thickness that follow the outlines of vesicular, glassy coarse ash and lapilli in thin sections from the 2017 drill cores (Fig. 2). Subaerially-deposited tephra of the Surtur and Surtungur tuff cones contains abundant armoured
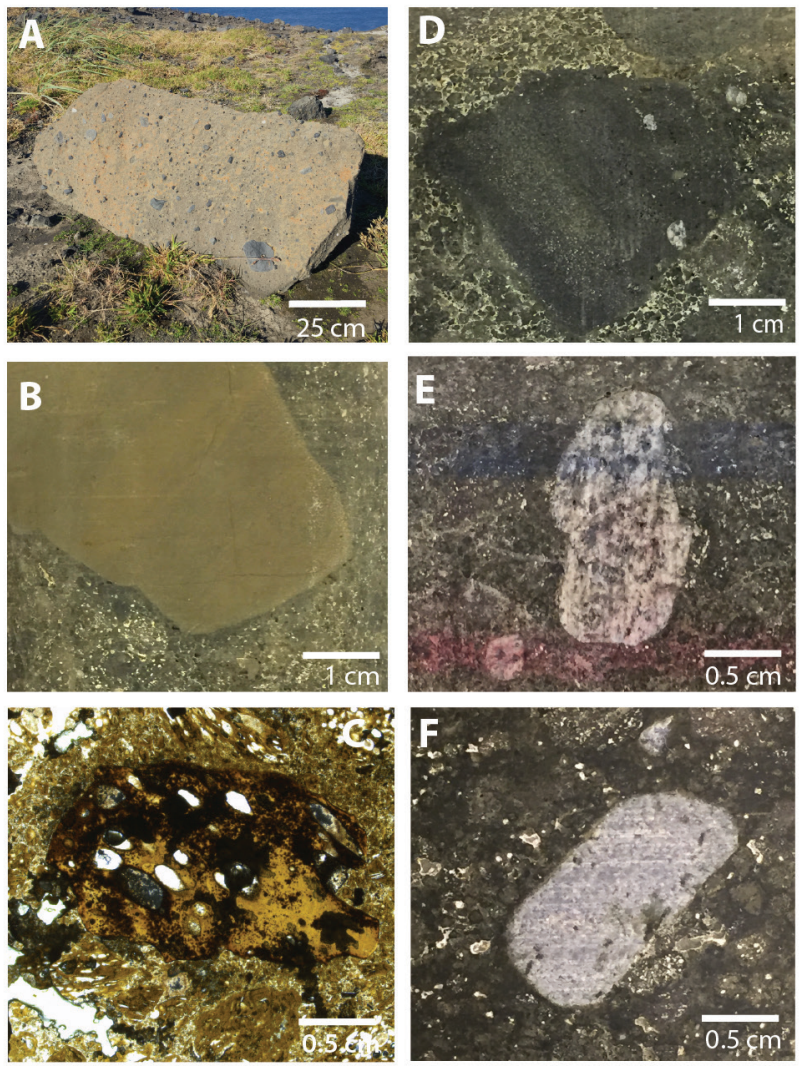

Figure 3. Examples of xenolithic fragments in 2017 Surtsey drill cores. A) Block of seafloor sedimentary rock, Surtur subaerial tuff cone. B) Subangular clast of basaltic glass , 80.5 m.b.s., SE-02A core. C) Photomicrograph of a subangular basaltic clast similar to (B) but strongly altered, 120.0 m.b.s., SE-03. D) Subangular basaltic clast with layering and plagioclase phenocrysts, 83.1 m.b.s., SE-02A. E) Two subrounded gneissic rock fragments, 125.1 m.b.s., SE-02A. F. Subrounded granitic rock fragment, 99.6 m.b.s., SE-02A. (A) Field photo, (B, D, E, F) Core photos, (C) Petrographic microscope image, ppl.

lapilli (Lorenz, 1974b, Jakobsson \& Moore 1982, Jackson et al. 2019a, McPhie et al. 2020). These are commonly associated with large vesicles in the tuff that record entrapment or entrainment of steam (or liquid water) (Lorenz 1974a, Lorenz 1986). In deeper lapilli tuff of the 1979 SE-01 Surtsey drill core, observations of narrow ash rims on lapilli and large irregularly-shaped pores $(>1 \mathrm{~mm})$ have been interpreted as indicators of landslides and slumps that re-mobilized freshly erupted subaerial tephra, along with steam or atmospheric gases (Moore 1985). Lithic fragments of seafloor rocks and exotic clasts (Alexandersson 1970, 1972, Baldursson \& Ingadóttir 2007, Reynisson \& Jakobsson 2009) (Fig. 3) in the lapilli tuff originated from the wall rock around the vent and conduit. They have been 

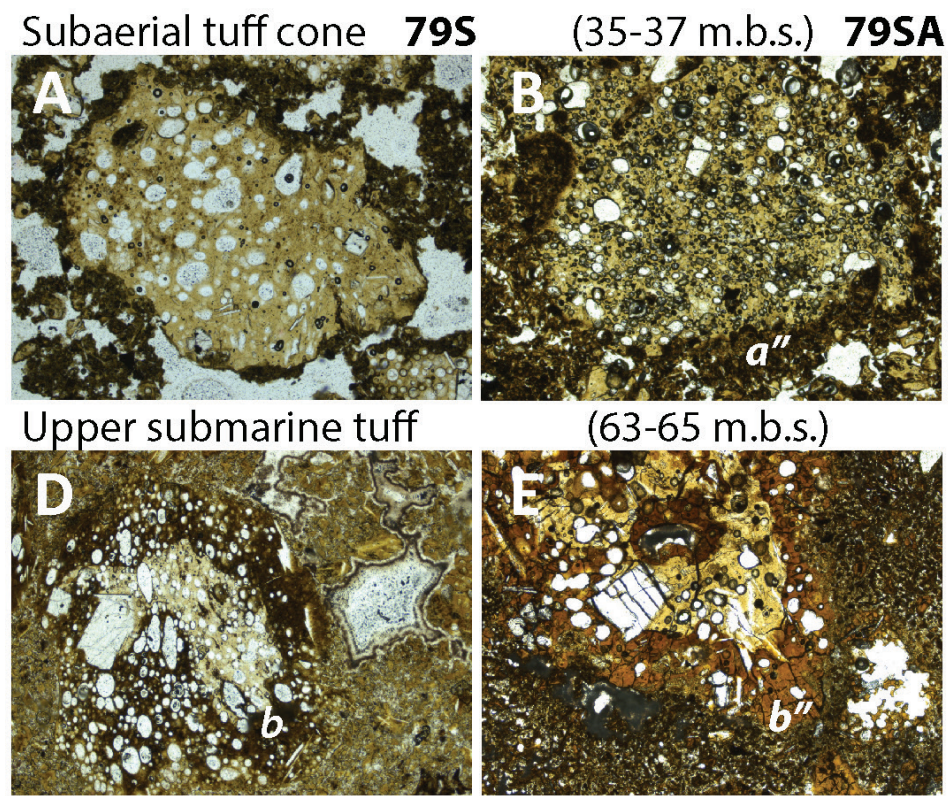

(63-65 m.b.s.)

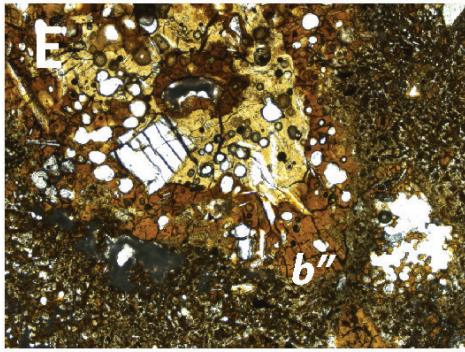

Maximum temperature zone $\quad(100-107$ m.b.s. $)$
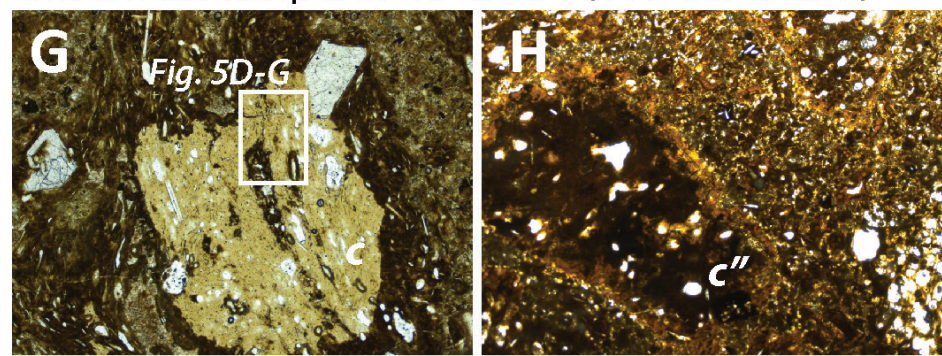

Submarine inflow zone

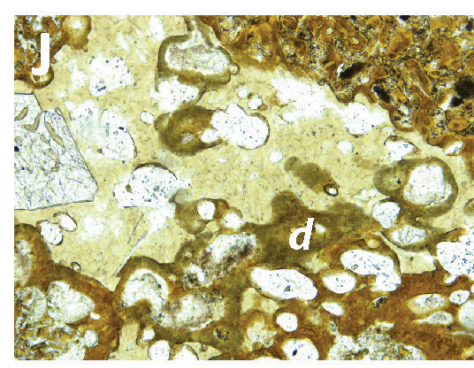

(145-148 m.b.s.)
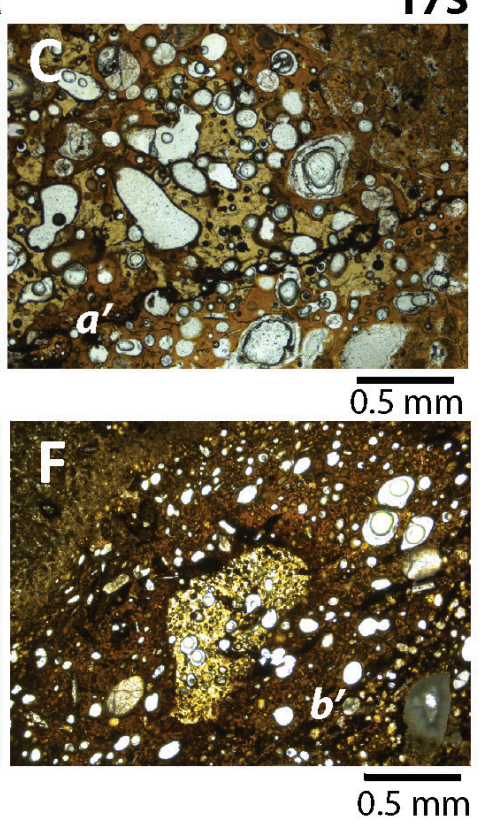

Lowermost borehole deposits (168-170 m.b.s.)
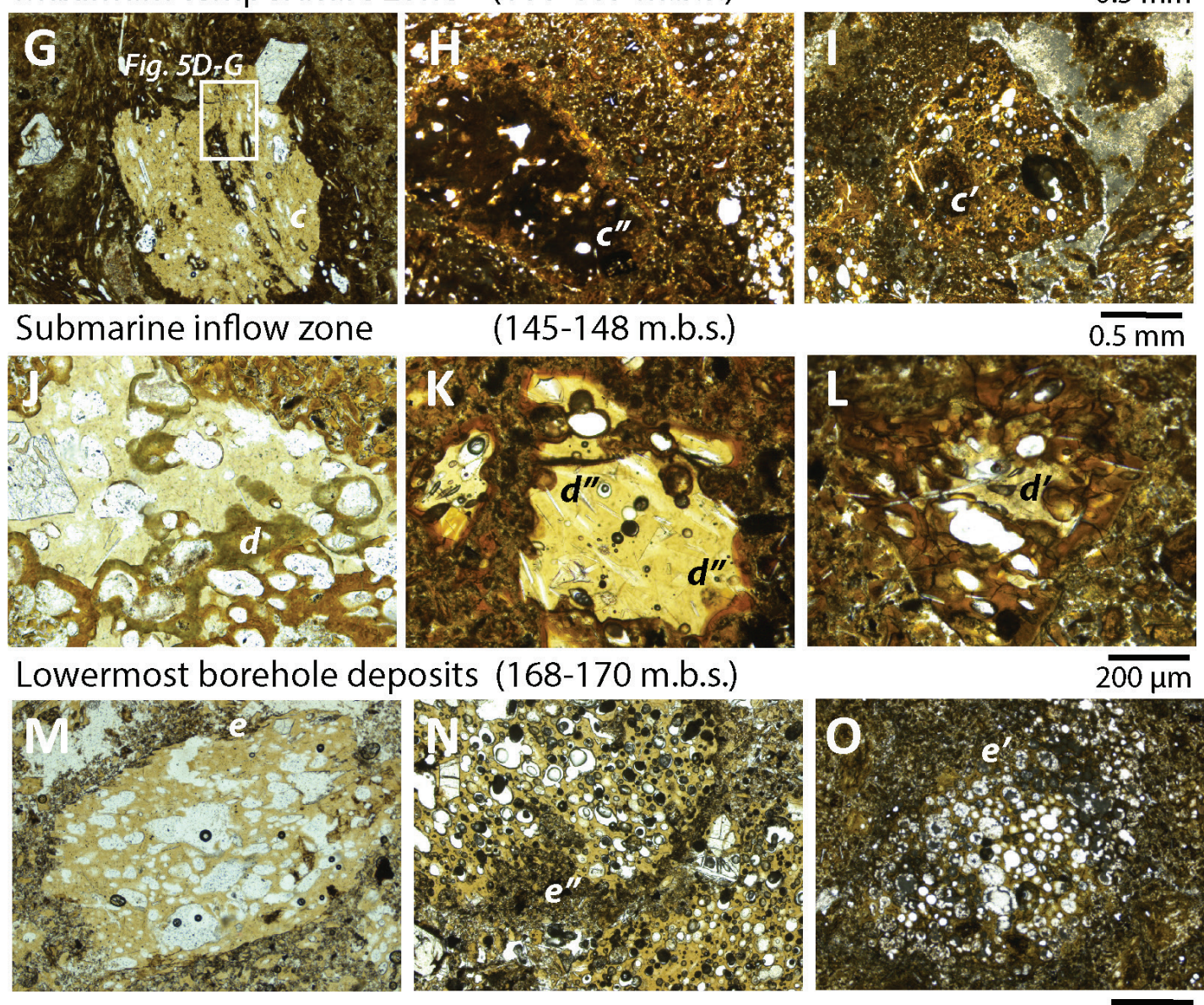

$\overline{0.5 \mathrm{~mm}}$

Figure 4. Petrographic images of glassy Surtsey pyroclasts in thin sections from samples of the 1979 drill core prepared in 1979 immediately after drilling (79S), the archived 1979 drill core prepared in 2016 - 2018 (79SA), and the 2017 drill cores prepared in 2017 - 2019 (17S), ppl except (H). See Table 1 for Munsell Colours. Labels $a, a^{\prime}$, a”, etc. refer to sites in the 79S, 79SA and 17S thin sections described in the text. A) $79 S, 37.0$ m.b.s., $70.8^{\circ} \mathrm{C}$ in 1980 , B) $79 S A, 37.3$ m.b.s., C) $17 S, 34.5$ m.b.s., $36^{\circ} \mathrm{C}$ in 2017 , D) $79 S$, 63.1 m.b.s., $107.8^{\circ} \mathrm{C}$ in 1980 , E) $79 \mathrm{SA}$, 65.5 m.b.s., F) $17 \mathrm{~S}$, 65.8 m.b.s., $101^{\circ} \mathrm{C}$ in 2017 , G) $79 \mathrm{~S}, 107.5$ m.b.s., $140.8^{\circ} \mathrm{C}$ in $\left.1980, \mathrm{H}\right) 79 \mathrm{SA}, 102.6$ m.b.s. (xpl) I) $17 S, 100.0$ m.b.s., $125^{\circ} \mathrm{C}$ in 2017 , J) $79 S, 147.7$ m.b.s., $82.5^{\circ} \mathrm{C}$ in 1980 , K) $79 S A, 145.0$ m.b.s., L) $17 S, 145.6$ m.b.s., $85^{\circ} \mathrm{C}$ in 2017, M) $79 S, 168.9$ m.b.s., $70.6^{\circ} \mathrm{C}$ in 1980 , N) $79 S A, 170.1$ m.b.s., O) $17 S, 170.6$ m.b.s., $51^{\circ} \mathrm{C}$ in 2017 . Temperature measurements from Jakobsson \& Moore (1982), Jackson et al. (2019a). 
inferred to derive from explosive excavation of the seafloor by continuous uprush eruptions underlying the Surtur and Surtlungur craters (Moore 1985). The altered glass pyroclasts with narrow ash rims (Fig. 2) do not precisely resemble typical armoured lapilli, which have a round outer margin and fine ash coating that is millimeters in thickness (McPhie et al. 2020, their figs. 4d, 6b).

The petrographic studies then describe characteristics of altered glass in the original thin sections of the 1979 SE-01 drill core prepared in 1979 (79S) and thin sections from the 2017 SE-02A, SE-02B and SE-03 drill cores prepared in 2017 2019 (17S) (Fig. 4). These samples record changes in glass alteration that occurred over 38 years within the principal hydrothermal and structural zones of the volcano: (1) the subaerial tuff cone above water level at approximately $0-58 \mathrm{~m}$ below surface (m.b.s.), (2) the upper submarine tuff, (3) the higher temperature hydrothermal zone, (4) the submarine inflow zone of weakly-lithified tephra where cooler water of higher salinity enters the borehole (Jackson et al. 2019a), (5) the lowermost tephra and tuff above the pre-eruption seafloor at approximately $168-181$ m.b.s., and (6) the sub-seafloor tuff at approximately $185-290$ m.b.s. (Fig. 1, zones 1-6). The depths do not necessarily indicate where the tephra was first deposited or where the characteristics of the sample first formed.

Associated changes in the oven dry density and water absorption characteristics of drill core samples from these deposits are briefly described (Fig. 5). The labile nature of Surtsey basaltic glass and a possible propensity to undergo change in the repository environment is then explored with descriptions of altered glass in thin sections prepared from the 1979 drill core archive (79SA) in $2016-2018$ from the same alteration zones. These samples experienced about 12 years in the volcanic environment and about 38 years in the repository environment, while stored in wooden core boxes under room temperature conditions. The comparison of petrographic features of glass alteration in the 1979 and 2017 volcanic environments (79S and $17 S$ ) with the 1979 mixed volcanic and archival environments (17SA) provide reference guidelines for assessing the instability of the glass phase under the evolving conditions of the volcanic environment as well as the curatorial conditions of the repository environment.
The petrographic studies also explore the presence of microtubular structures that resemble endolithic microborings in the original thin sections of the 1979 drill core (Fig. 6). The term, endolith, defines an organism that penetrates actively into the interior of rocks forming tunnels or microborings (Fisk et al. 2003, Staudigel et al. 2008, Walton 2008, Fisk \& McLoughlin 2013). The main threat to the survival of organisms in basalt seems to result from increases in temperature. Hyperthermophile organisms, commonly in domain Archaea, can thrive in extremely hot environments, $80^{\circ} \mathrm{C}$, and some bacteria are able to tolerate temperatures of $100{ }^{\circ} \mathrm{C}$. However, the inferred temperature maximum for functional microbial life is thought to be $120{ }^{\circ} \mathrm{C}$ (Ivarsson et al. 2015, Kashefi \& Lovley 2003, Prieur \& Marteinsson 1998). This implies that submarine deposits at Surtsey from $80-130$ m.b.s. that reached $120-141{ }^{\circ} \mathrm{C}$ borehole temperatures in 1980 (Jakobsson \& Moore 1982) (Fig. 1) could be

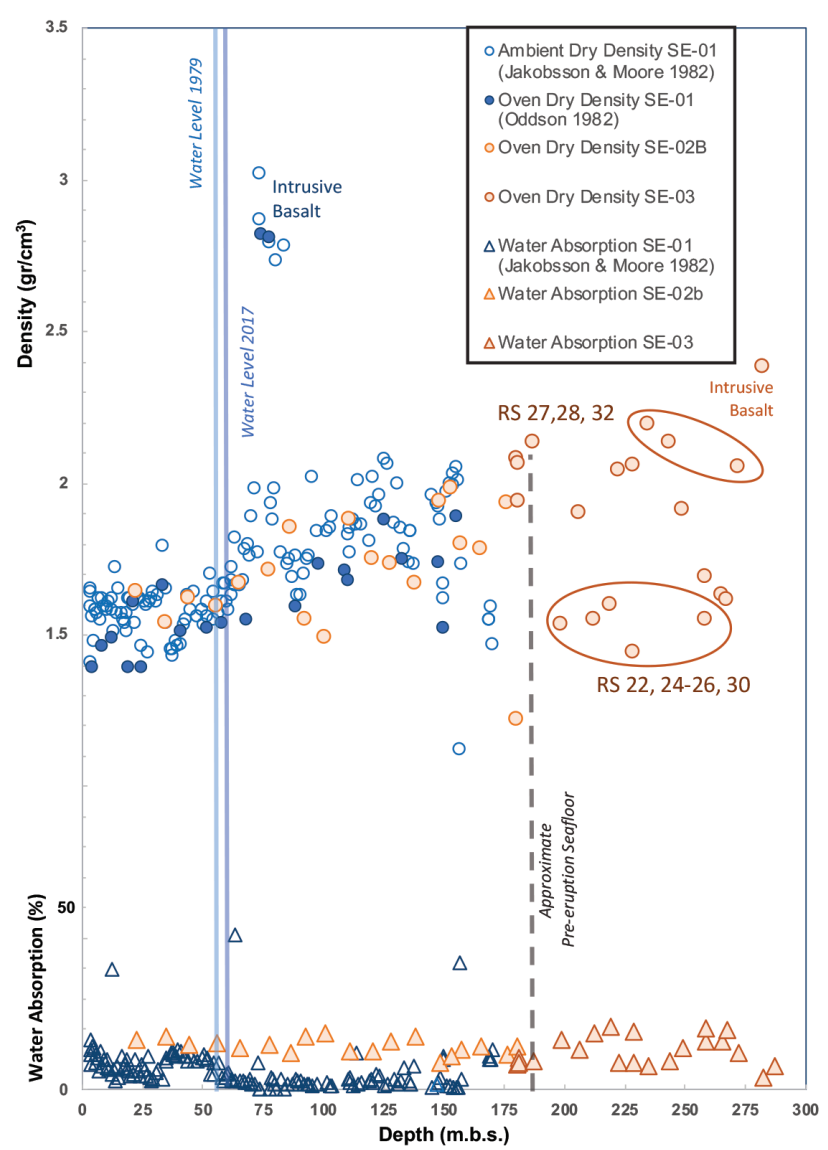

Figure 5. Water absorption and rock density of Surtsey lapilli tuff and basaltic intrusions, based on measurements by Jakobsson \& Moore (1982), Oddson (1982), and Jackson et al. (2019a). 
inhospitable environments for functional microbial activity. By contrast, the possible preservation of traces of endolithic microbial activity in residual fresh glass of the highly altered tuff would suggest that the initial temperatures of the freshly erupted tephra deposits were less than about $80-100{ }^{\circ} \mathrm{C}$, as hypothesized by Jakobsson \& Moore (1982).

\section{MATERIAL AND METHODS}

Petrographic studies of thin sections used an Olympus BX53M microscope in the Department of Geology and Geophysics, University of Utah, to compare features in thin sections of Surtsey basaltic tuff samples from the 1979 SE-01 core prepared immediately after drilling in 1979 (the $79 S$ sections), the 1979 SE-01 core prepared in 2016 - 2018 after archival storage for 38 years in wooden core boxes (the 79SA sections), and the
2017 SE-02A, SE-02B and SE-03 cores, prepared in 2017 - 2019 (the $17 S$ sections). The 2017 samples are wrapped tightly in plastic and stored under refrigeration at $2{ }^{\circ} \mathrm{C}$. All sections were prepared at standard $0.3 \mathrm{~mm}$ thickness. The $79 \mathrm{~S}$ thin sections were first described by Jakobsson \& Moore $(1982,1986)$; they have glass cover slips. The 79SA and $17 S$ thin sections were polished and prepared with superglue and no heat treatment in the laboratory of Burnham Petrographics, L.L.C. to facilitate detachment of the rock slice for finescale diffraction and spectroscopic investigations (e.g. Jackson et al. 2019b). A suite of 32 reference samples (RS) from the 2017 cores was distributed to the SUSTAIN science team to facilitate collaborative research; these are designated by an RS sample name. All colours are described with Munsell Colour notation, as distinguished by the
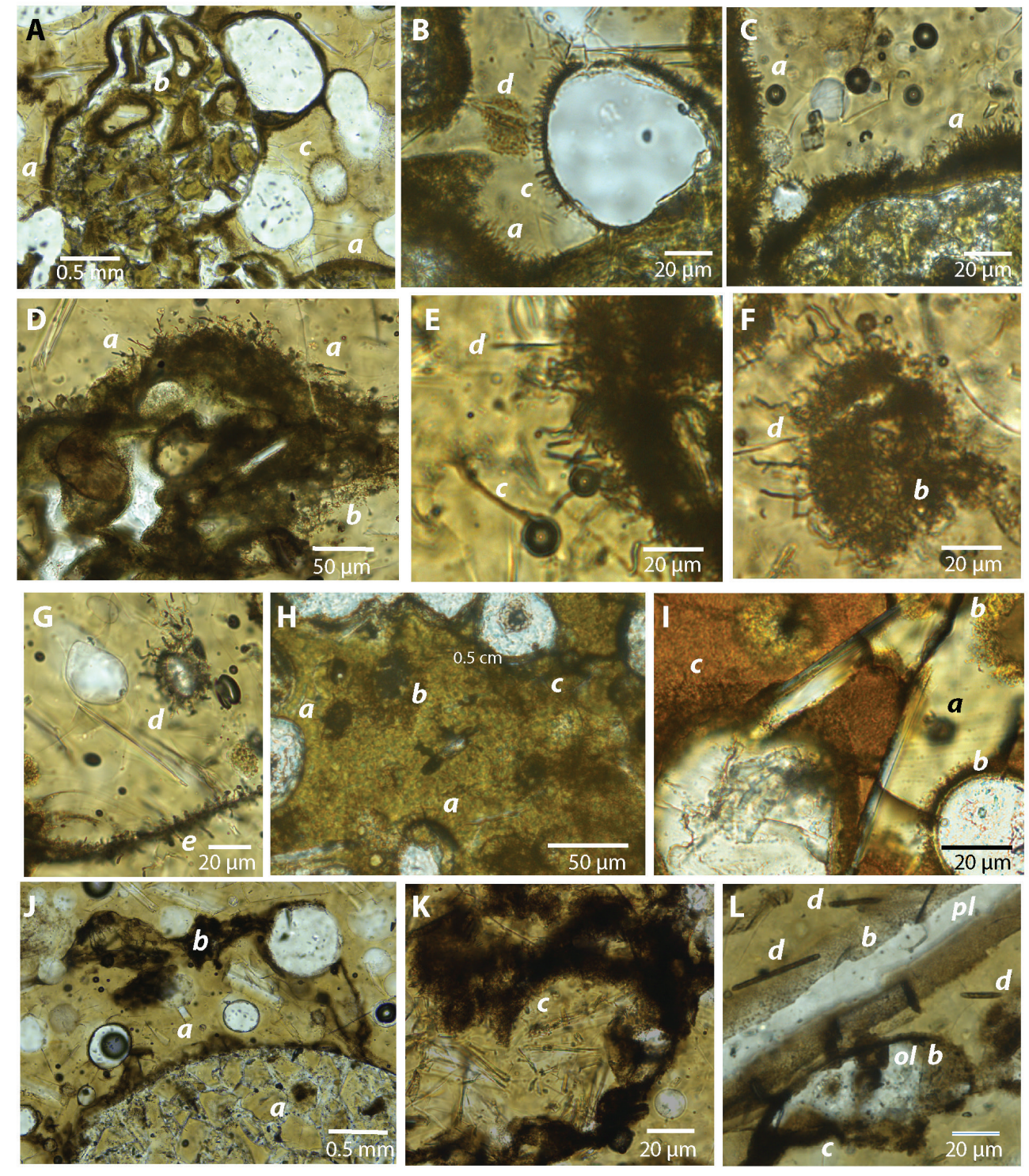

Figure 6. Petrographic images of microtubule and granular microstructures, interfacial zones with narrow protrusions, and possible endolithic microborings in glass lapilli in the original 1979 Surtsey thin sections (79S), ppl. Labels $a, b, c, d$ refer to sites described in the text; ol, olivine, pl, plagioclase. A, B, C) $79 \mathrm{~S}, 36.4$ m.b.s., 70.8 ${ }^{\circ} \mathrm{C}$ in 1980. D, E, F, G) 79S, 107.5 m.b.s., $140.8^{\circ} \mathrm{C}$ in 1980 (see Fig. 4G). H) 17S, 100.1 m.b.s., $141.3^{\circ} \mathrm{C}$ in $1980,126^{\circ} \mathrm{C}$ in 2017 . I) $17 S, 145$ m.b.s., $82.5^{\circ} \mathrm{C}$ in 1980, $100.2^{\circ} \mathrm{C}$ in 2017 . J, K, L, M) 79S, 168.9 m.b.s., $70.6{ }^{\circ} \mathrm{C}$ in 1980 . Temperature measurements from Jakobsson \& Moore (1982), Jackson et al. (2019a). 
Table 1. Munsell colours of altered glass in the plane polarized light of petrographic microscopy. Surtsey drill cores SE-01 and SE-02A, SE-02B.

\begin{tabular}{|c|c|c|c|}
\hline Sample Name & $\begin{array}{l}\text { Translucent "Glass" } \\
\text { Pyroclast Interior }\end{array}$ & $\begin{array}{l}\text { Altered Glass } \\
\text { Palagonitized Rind } \\
\text { Pyroclast Margin }\end{array}$ & $\begin{array}{l}\text { Altered Glass } \\
\text { Fine Ash }\end{array}$ \\
\hline \multicolumn{4}{|c|}{ Subaerial Tuff Cone $35-37$ m.b.s. } \\
\hline $79 \mathrm{~S}-37.0 \mathrm{~m}$ & Yellowish gray 5 Y 7/2 & $\begin{array}{l}\text { Moderate yellow brown } 5 \mathrm{Y} 4 / 4 \\
\text { to Olive gray } 5 \mathrm{Y} 3 / 2 \text { (rare) }\end{array}$ & $\begin{array}{l}\text { Dark greenish yellow } 10 \mathrm{Y} 6 / 6 \\
\text { to Moderate greenish yellow } 10 \mathrm{Y} 6 / 4\end{array}$ \\
\hline 79SA-37.3m & Yellowish gray $5 Y$ 7/2 & Dusky olive brown 5Y 3/4 (rare) & $\begin{array}{l}\text { Light olive brown } 5 \mathrm{Y} 4 / 4 \\
\text { to Olive gray } 5 \mathrm{Y} 3 / 2\end{array}$ \\
\hline $17 \mathrm{~S}-34.5 \mathrm{~m}$ & $\begin{array}{l}\text { Yellowish gray } 5 Y 7 / 2 \\
\text { (rare) }\end{array}$ & $\begin{array}{l}\text { Moderate yellowish orange } 10 \mathrm{YR} 7 / 6 \\
\text { to Light brown 5YR 5/6 (common) } \\
\text { (birefringent) }\end{array}$ & $\begin{array}{l}\text { Yellowish orange } 10 \mathrm{YR} 7 / 6 \\
\text { to Dark yellowish orange } 10 \mathrm{YR} 5 / 6 \\
\text { (very weakly birefringent) }\end{array}$ \\
\hline \multicolumn{4}{|c|}{ Upper Submarine Zone 63 - 65 m.b.s. } \\
\hline $79 \mathrm{~S}-63.1 \mathrm{~m}$ & Yellowish gray $5 Y$ 7/2 & $\begin{array}{l}\text { Moderate yellow } 5 \mathrm{Y} 6 / 6 \\
\text { to Moderate olive brown } 5 \mathrm{Y} 4 / 4 \\
\text { (birefringent) }\end{array}$ & $\begin{array}{l}\text { Moderate yellow } 5 \text { Y } 7 / 6 \\
\text { to Dusky yellow } 5 \text { Y } 6 / 4 \\
\text { (very weakly birefringent) }\end{array}$ \\
\hline 79SA-65.6m & Yellowish gray 5 Y 7/2 & $\begin{array}{l}\text { Pale yellowish orange } 10 \text { YR } 8 / 6 \\
\text { to Light brown } 5 \text { YR 5/6 } \\
\text { (birefringent) }\end{array}$ & $\begin{array}{l}\text { Pale yellowish orange } 10 \text { YR } 8 / 6 \\
\text { to Moderate olive brown } 5 Y 4 / 4 \\
\text { (weakly birefringent) }\end{array}$ \\
\hline $17 \mathrm{~S}-65.8 \mathrm{~m}$ & Not present & $\begin{array}{l}\text { Dark yellowish orange 10YR 6/6 } \\
\text { to Light brown 5YR 6/6 (rare) } \\
\text { (birefringent) } \\
\text { Moderate brown 5YR 3/4 (common) } \\
\text { (not birefringent) }\end{array}$ & $\begin{array}{l}\text { Dark yellowish orange } 10 \text { YR } 5 / 6 \\
\text { to Dark yellowish brown } 10 \text { YR } 3 / 2 \\
\text { (very weakly birefringent) }\end{array}$ \\
\hline \multicolumn{4}{|c|}{ Maximal Temperature Zone 100 - 107 m.b.s. } \\
\hline $79 \mathrm{~S}-107.5 \mathrm{~m}$ & $\begin{array}{l}\text { Yellowish gray } 5 \text { Y 7/2 } \\
\text { (rare) }\end{array}$ & $\begin{array}{l}\text { Light olive } 10 \mathrm{Y} 5 / 4 \\
\text { to Grayish olive } 10 \mathrm{Y} 4 / 2 \\
\text { to Olive gray } 5 \mathrm{Y} 4 / 2 \text { (rare) } \\
\text { (weakly birefringent) }\end{array}$ & $\begin{array}{l}\text { Pale olive } 10 \mathrm{Y} 6 / 2 \\
\text { to Light olive brown } 5 \text { Y } 5 / 6 \\
\text { (very weakly birefringent) }\end{array}$ \\
\hline 79SA-102.6m & Not present & $\begin{array}{l}\text { Moderate yellowish brown } 10 \mathrm{YR} 6 / 4 \\
\text { to Moderate yellow orange } 10 \mathrm{YR} 7 / 6 \\
\text { (rare) (birefringent) }\end{array}$ & $\begin{array}{l}\text { Light brown } 5 \text { YR } 4 / 6 \\
\text { to Grayish brown } 5 \text { YR } 3 / 2 \\
\text { (very weakly birefringent) }\end{array}$ \\
\hline $17 \mathrm{~S}-100.1 \mathrm{~m}$ & Not present & $\begin{array}{l}\text { Moderate yellow brown } 5 \text { Y } 6 / 6 \\
\text { to Moderate olive brown } 5 \text { Y } 4 / 4 \\
\text { to Olive gray } 5 \text { Y } 3 / 2 \text { (rare) } \\
\text { (birefringent) }\end{array}$ & $\begin{array}{l}\text { Moderate olive brown } 5 \mathrm{Y} 4 / 4 \\
\text { to Olive gray } 5 \mathrm{Y} 3 / 2 \\
\text { (weakly birefringent) } \\
\text { (also lapilli interiors) }\end{array}$ \\
\hline \multicolumn{4}{|c|}{ Submarine Inflow Zone 145 - 148 m.b.s. } \\
\hline $79 \mathrm{~S}-147.7 \mathrm{~m}$ & Yellowish gray $5 \mathrm{Y} 7 / 2$ & $\begin{array}{l}\text { Light olive } 10 \mathrm{Y} 5 / 4 \\
\text { (vesicle rims, not birefringent) } \\
\text { Moderate greenish yellow } 10 \mathrm{YR} 6 / 4 \\
\text { to Light olive brown } 5 \mathrm{Y} 5 / 6 \\
\text { (weakly birefringent) }\end{array}$ & $\begin{array}{l}\text { Moderate greenish yellow } 5 \text { Y } 6 / 6 \\
\text { to Moderate yellow } 5 \text { Y } 6 / 6 \\
\text { (very weakly birefringent) }\end{array}$ \\
\hline 79SA-145.0m & Grayish yellow $5 \mathrm{Y} 8 / 4$ & $\begin{array}{l}\text { Moderate yellow 5Y 7/6 } \\
\text { (not birefringent) } \\
\text { Moderate yellow orange 10YR 7/6 } \\
\text { to Light brown 5YR 5/6 } \\
\text { (weakly birefringent) }\end{array}$ & $\begin{array}{l}\text { Moderate yellow 5Y } 7 / 6 \\
\text { (not birefringent) } \\
\text { Moderate yellow orange 10YR 7/6 } \\
\text { (weakly birefringent) }\end{array}$ \\
\hline $17 \mathrm{~S}-148.4 \mathrm{~m}$ & $\begin{array}{l}\text { Yellowish gray } 5 \mathrm{Y} 7 / 2 \\
\text { (rare) }\end{array}$ & $\begin{array}{l}\text { Dark yellowish orange } 10 \text { YR 6/6 } \\
\text { to Light brown 5YR 5/6 } \\
\text { (weakly birefringent) }\end{array}$ & $\begin{array}{l}\text { Moderate yellow } 5 \text { Y } 6 / 6 \\
\text { to Dark yellowish orange } 10 \text { YR } 6 / 6 \\
\text { to Light brown } 5 \text { YR } 5 / 6 \\
\text { (very weakly birefringent) }\end{array}$ \\
\hline \multicolumn{4}{|c|}{ Lowermost borehole deposits 168 - 170 m.b.s. } \\
\hline $79 \mathrm{~S}-168.9 \mathrm{~m}$ & Yellowish gray $5 Y$ 7/2 & $\begin{array}{l}\text { Moderate yellow brown } 5 Y 4 / 4 \\
\text { (opaque borders and zones) }\end{array}$ & $\begin{array}{l}\text { Yellowish gray } 5 \mathrm{Y} 7 / 2 \\
\text { Dark gray } \mathrm{N} 2 \\
\text { (fine dark gray ash) }\end{array}$ \\
\hline 79SA-170.1m & Dusky yellow 5Y 6/4 & $\begin{array}{l}\text { Grayish brown } 5 \text { YR } 3 / 2 \\
\text { (opaque borders and zones) }\end{array}$ & $\begin{array}{l}\text { Dusky yellow } 5 \text { Y } 6 / 4 \\
\text { Dark gray N2 } \\
\text { (fine dark gray ash) }\end{array}$ \\
\hline $17 \mathrm{~S}-170.6 \mathrm{~m}$ & Not present & $\begin{array}{l}\text { Moderate yellow } 5 \text { Y } 6 / 6 \\
\text { to Light yellow brown } 5 \text { Y } 5 / 6 \\
\text { Moderate olive brown } 5 \text { Y 4/4 } \\
\text { (weakly birefringent) }\end{array}$ & $\begin{array}{l}\text { Light olive brown } 5 \mathrm{Y} 5 / 6 \\
\text { to Moderate olive brown } 5 \mathrm{Y} 4 / 4 \\
\text { to Olive gray } 5 \mathrm{Y} 3 / 2 \\
\text { (weakly birefringent) }\end{array}$ \\
\hline
\end{tabular}


Geological Society Rock Colour chart (Table 1). Colours were noted in plane polarized light (ppl) at 10X magnification and matched with the color chart in the light of a sunlit window. Note that the colours shown by the micrographs (Figs. $2,4,5)$ do not always represent the true colours in ppl (Table 1). Rock density measurements by Oddson (1982) and this study and measurements of water absorption, [(weight in air ${ }_{\text {water saturated }}$ weight in $\operatorname{air}_{\text {oven dry }}$ )/ weight in air ${ }_{\text {oven dry }}$, follow the guidelines of the American Standards of Testing Materials (ASTM C97/C97M-18). Measurements recorded by Jakobsson \& Moore (1982) did not oven dry specimens before water saturation and so give lower water absorption values (Fig. 5). Temperatures refer to measurements in borehole SE-01 in September 1980 and August 2017 and in borehole SE-03 ten days post-drilling in September 2017 (Jakobsson \& Moore 1982, Jackson et al. 2019a).

\section{RESULTS}

Narrow ash rims on glass pyroclasts

Armoured lapilli tuff is the dominant facies in 2017 borehole SE-02A above water level and in 2017 borehole SE-03, at various levels above 70 $\mathrm{m}$ measured depth (McPhie et al. 2020). Some glassy coarse ash and lapilli in thin sections from the subaerial tuff cone deposits are outlined by a narrow rim of fine ash (Fig. 4A). The fine ash rims differ in particle shape, size, packing, porosity and/ or colour from the surrounding altered vitric ash matrix. The narrow rims do not precisely resemble the typical rounded form and thicker rims of very fine accretionary ash on armoured lapilli (Lorenz 1974a). Lapilli and coarse ash in certain submarine (Fig. 2AC) and sub-seafloor (Fig. 2D-F) tuff deposits from the 2017 SE-02B and SE-03 drill cores also have these unusual, narrow rims of fine ash. For example, in submarine tuff at 65.8 m.b.s., just below the zone of tidal flux (Fig. 1), a vesicular, highly altered glass fragment has a $200-400 \mu \mathrm{m}$ border composed of fine ash and opaque, sub-angular, coarser ash that is more birefringent than the fine ash of the altered vitric matrix (Fig. 2A). In less altered tuff at 154.1 m.b.s., a weakly altered, vesicular glass fragment has an intermittent, $200-300 \mu \mathrm{m}$ thick rim composed of dark gray (N2) fine ash and sparse moderate yellow (5Y 6/6) coarser ash (Fig. 2B); the fine ash is darker and more opaque than that of the altered vitric matrix.
In the lowermost SE-02B core at 170.6 m.b.s., clots of ash $0.5-1.5 \mathrm{~cm}$ in diameter have $100-300 \mu \mathrm{m}$ rims of moderate olive brown (5Y 4/4) subangular fine ash (Fig. 2C). At 220.3 - 220.7 m measured depth (180.5 m.b.s.) in the SE-03 core, a highly altered, vesicular glass fragment has a porous $50-100 \mu \mathrm{m}$ rim of angular, light to moderate olive brown ( 5 Y 5/6 $-5 \mathrm{Y} 4 / 4$ ) fine ash; the rim is separated from the ash matrix by pores $1-2 \mathrm{~mm}$ in length, now partially filled with mineral cements (Fig. 2D, sample RS19). Tuff samples from porous zones at $258.9-259.3 \mathrm{~m}$ measured depth (212.0 m.b.s.) and $267.2-267.6 \mathrm{~m}$ measured depth (218.9 m.b.s.), about $25-35$ m below the pre-eruptive seafloor (Fig. 1), contain abundant altered glass fragments outlined with narrow rims of ash (Fig. 2E-F, samples RS24, RS25). For example, the vesicular glass fragment at 212 m.b.s. is isolated from the altered vitric matrix by nearly contiguous pores $0.25-2 \mathrm{~mm}$ in length and width. It has a 300 $-500 \mu \mathrm{m}$ rim of very fine, compact, olive gray (5Y 3/2) ash (Fig. 2E). The vesicular glass pyroclast at 219 m.b.s. has an intermittent rind of altered glass, about $15 \mu \mathrm{m}$ in thickness (Fig. 2F). It is also isolated from the vitric matrix by large, irregularly-shaped pores, but these are filled with mineral cements. The rim, $15-800 \mu \mathrm{m}$ in thickness, is composed of subangular, olive gray (5Y 3/2) fine ash and light brown (5YR 4/6) coarser ash. The vesicular pyroclast has an intermittent rind of altered glass, about $15 \mu \mathrm{m}$ in thickness.

\section{Examples of lithic fragments}

The tuff deposits on the surface of Surtsey contain two principal groups of xenoliths: pre-eruption seafloor sedimentary rock deposited on the insular terrace underlying the volcano during and following glacial periods, and ice-rafted debris carried in from afar before the growth of the volcano (Alexandersson 1970, 1972, Baldursson \& Ingadóttir 2007, Reynisson \& Jakobsson 2009). The marine sedimentary rock of volcanic origin was lithified before Surtsey erupted. The largest rock fragments exposed on the subaerial tuff cone are about one meter in diameter (Fig. 3A). These commonly have a compact matrix of subrounded glass particles and abundant sub-angular, sand- to coarse gravel-sized clasts of coherent basalt The fragments in the drill cores range from relatively unaltered (Fig. 3B) to highly altered with authigenic mineral cements (Fig. 3C), principally zeolites and Al-tobermorite growing in relict pores. Angular 
fragments of coherent basalt (Fig. 3D) are common. Exotic crystalline rocks, gneissic and granitic pebbles most likely derived from Greenland (Fig. 3E, F), were transported by icebergs into the region and deposited with the sediments underlying the volcano (Reynisson \& Jakobsson 2009). The volume of sedimentary rock that underlay the volcano and was carried to the surface is difficult to estimate, since only the largest xenoliths are clearly recognizable.

\section{Petrographic comparisons of glass alteration}

Rates of glass alteration in the SE-01 drill core were quantified immediately after drilling in 1979 through measurements of the thicknesses of palagonitized rinds on coarse ash- and lapilli-sized glass fragments and alteration rims on olivine crystal fragments (Jakobsson \& Moore 1986). The growth rates ranged from about $1 \mu \mathrm{m} /$ year at $60^{\circ} \mathrm{C}$ to $5-10 \mu \mathrm{m} /$ year at 100 ${ }^{\circ} \mathrm{C}$. Examples of those alteration features are shown in the first panel of Figure 4 (79S) and described with Munsell Colours in Table 1. At 37.0 m.b.s. in the subaerial tuff cone a translucent, yellowish gray (5Y $7 / 2$ ) glass fragment with a narrow irregular rim of fine ash shows little palagonitic alteration (Fig. 4A). By contrast, the glass fragment at 63.1 m.b.s. in the upper submarine zone has a thick rind (up to $500 \mu \mathrm{m}$ ) of moderate yellow (5Y 6/6) to moderate olive brown (5Y 4/4) palagonitized glass (Fig. 4D, site $b$ ). At 107.5 m.b.s. in the higher temperature hydrothermal zone, most lapilli are pervasively altered. However, one pyroclast preserves translucent, yellowish gray (5Y $7 / 2$ ), apparently fresh glass that contains granular and tubular microstructures (Figs. 4G, site $c$, 6D-G). In the submarine inflow zone at 147.7 m.b.s., a lapillus also preserves apparently fresh, yellowish gray (5Y $7 / 2)$ glass. The internal vesicles have $20-30 \mu \mathrm{m}$ light olive (10Y 5/4) alteration rinds; broad zones of unusual moderate greenish yellow (10YR 7/6) to light olive brown (5Y 6/6) altered glass occur around the perimeter (Fig. 4J, site $d$ ). In the lowermost core at 168 m.b.s., apparently fresh, yellowish gray (5Y 7/2) glass is preserved, but opaque, isotropic, moderate yellow brown $(5 \mathrm{Y} 4 / 4)$ zones of altered fine ash are common in the matrix surrounding larger clasts (Fig. 4M, site $e$ ).

Vesicular, glassy coarse ash and lapilli in $17 \mathrm{~S}$ thin sections show a pronounced progression of palagonitic alteration relative to that recorded in the $79 S$ thin sections. In the subaerial tuff cone at 34.5 m.b.s. and in the uppermost submarine zone at 65.8 m.b.s., the yellowish gray (5Y 7/2) clast interiors do not have the clear and translucent aspect of apparently fresh $79 S$ glass (Fig. 4A, C). The altered rinds range from yellowish orange (10YR 7/6) to dark yellowish orange (10YR 5/6) and dark yellowish brown (10YR 3/2) (Fig. 4C, F, site $a$ ', Table 1); smaller glass particles are more pervasively altered. In the higher temperature hydrothermal zone at 100.1 m.b.s., the palagonitized rinds have become birefringent (Fig. 4I). Areas occupied by apparently fresh, yellowish gray $(5 \mathrm{Y} 7 / 2)$ glass in the $79 S$ thin sections (Fig. $4 \mathrm{G}$, site $c$ ) are opaque and isotropic in the $17 S$ thin sections (Fig. 4I, site $c^{\prime}$ ). The $17 S$ palagonitized glass rinds retain the same olive brown $(5 \mathrm{Y} 4 / 4)$ and olive gray (5Y 3/2) hues as the $79 S$ rinds, but have developed weak birefringence (Table 1). In the submarine inflow zone at 148.4 m.b.s. only sparse glass particles retain yellowish gray (5Y 7/2) interiors; thick rinds (up to $450 \mu \mathrm{m}$ ) of weakly birefringent, dark yellowish orange (10YR 6/6) and light brown (5YR 5/6) palagonitized glass occur at clast perimeters (Fig. $4 \mathrm{~L}$, site $d^{\prime}$ ). In the lowermost SE-02B core at 170.6 m.b.s., the altered glass of clast interiors is opaque and non-birefringent (Fig. 4O); palagonitized glass rinds, however, preserve the same moderate yellow (5Y 6/6) and light yellow brown (5Y 5/6) colours of $79 S$ rinds at the same depth (Fig. 4M, site $e$, Fig. 4O, site $e^{\prime}$, Table 1).

The submarine 1979 core was dusky green to grayish olive green ( $5 \mathrm{G} 3 / 2$ to $5 \mathrm{GY} 3 / 2)$ when drilled and first placed in core boxes (Jakobsson \& Moore 1982), but after years of storage the green colour has vanished and the surface colour of the 79SA core is now dark to moderate yellowish brown (10YR 4/2 to 10YR 5/4). Petrographic features of altered glass in the 79SA thin sections differ from those of the 79S thin sections - and also from the $17 \mathrm{~S}$ thin sections. In the subaerial tuff cone at 37.3 m.b.s., internal zones retain a yellowish gray (5Y 7/2) colour (Fig. 4B) but lack the clear, translucent aspect of the apparently fresh glass of the $79 \mathrm{~S}$ thin section at 37.0 m.b.s. (Fig. 4A). Rare palagonitized rinds resemble those of the $17 \mathrm{~S}$ thin section at 34.5 m.b.s. (Fig. $4 \mathrm{C}$, site $a^{\prime}$ ), but are dusky olive brown (5Y 3/4) and more opaque (Fig. 4B, site $a$ ", Table 1). In the upper submarine zone at $65.6 \mathrm{~m}$.b.s., the thicknesses of palagonitized rinds on glassy particles (Fig. 4E, site $b$ ") are similar to those of the $79 S$ thin section (Fig. 4D, site $b$ ) but the colours more closely resemble the pale yellowish orange (10YR 7/6) of $17 S$ rinds (Figs. 4F, site $b^{\prime}$ ). 
In the high temperature hydrothermal zone at 102.6 m.b.s., the internal zones of some 79SA glass fragments are altered to an opaque, isotropic mass (Fig. 4H, site $c$ "). X-ray microdiffraction analyses demonstrate that this is mainly nano-crystalline nontronite (Jackson et al. 2019b, their fig. 4) and record the progressive organization of the incipient clay mineral structure. Altered glass rinds are weakly birefringent. None of the apparently fresh, yellowish gray (5YR 7/2) glass of the $79 S$ thin section at 107.5 m.b.s. (Fig. $4 \mathrm{G}$, site $c$ ) is present. The greater opacity of the ash matrix in the submarine 79SA thin sections (Fig. 4E, H) may result from crystallization of analcime. By contrast in the submarine inflow zone at 145.0 m.b.s., a $79 S A$ glass fragment has a weakly altered, grayish yellow (5Y 8/4) interior (Fig. 4K). The altered glass rinds around internal vesicles are moderate yellow (5Y 7/6) (Fig. 4K, site d") and preserve none of the light olive (10Y 5/4) hue of the internal rinds in the $79 S$ thin section at this depth (Fig. $4 \mathrm{~J}$, site $d$ ); instead, they more closely resemble the moderate yellow (5Y 6/6) of $17 S$ rinds (Fig. $4 \mathrm{~L}$, site $d$ ', Table 1). In the lower core at 170.1 m.b.s., internal zones of 79SA lapilli remain yellowish gray (5YR 7/2) (Fig. 4N); at 157.1 m.b.s., X-ray microdiffraction investigations of a similar 79SA yellowish gray (5YR $7 / 2$ ) internal zone indicates that fresh unaltered glass does indeed persist (Jackson et al. 2019b, their fig. 2). The opaque borders and irregular alteration zones are

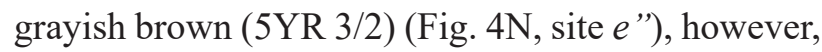
rather than the moderate yellow brown $(5 \mathrm{Y} 4 / 4)$ of $79 S$ lapilli (Fig. 4M, site $e$ ).

\section{Rock density and water absorption}

The oven-dry density of 2017 SE-02B drill core samples shows a wide range of scatter in the approximately $180 \mathrm{~m}$ thick sequence of lapilli tuff also sampled by the 1979 SE-01 drill core (Fig. 5). Measurements of the SE-02B samples were made in 2017 immediately after drilling. They yield an average oven-dry density, $1.70 \mathrm{~g} / \mathrm{cm}^{3}$, which is slightly higher than the average of the oven-dry SE01 measurements made in $1980,1.60 \mathrm{~g} / \mathrm{cm}^{3}$ (Oddson 1982, Jackson et al. 2019a). The SE-01 core samples measured by Jakobsson \& Moore (1982) were not oven-dried and so yielded higher values.

Measurements of water absorption in the SE-01 core samples show a pronounced increase at 35 55 m.b.s. (Jakobsson \& Moore 1982). This increase may reflect higher porosity near the zone of tidal flux in samples that were not oven-dried (J. G. Moore, personal communication, 2019). By contrast, water absorption measurements of the oven-dried SE02B core samples at these depths show little or no change. There, oven-dried densities range from 1.62 $-1.71 \mathrm{~g} / \mathrm{cm}^{3}$ compared with $1.51-1.55 \mathrm{~g} / \mathrm{cm}^{3}$ for the oven-dried SE-01 core samples (Oddson 1982, Jackson et al. 2019a). The development of mineral cements that now fill much of the original porosity seems to have slightly increased the density of the lapilli tuff.

The oven-dried density of the lapilli tuff in the lower sections of the 2017 SE-03 drill core also shows a great deal of variation. Lapilli tuff samples at 198.7, 212.0, 218.9, 228.6 and 258.5 m.b.s. (242.6, 258.9, 267.3, 279.1 and $315.6 \mathrm{~m}$ measured depth) give low oven-dried density, $1.40-1.70 \mathrm{~g} / \mathrm{cm}^{3}$ (Jackson et al. 2019a, samples RS 22, 24, 25, 26, 30). Thin sections of these samples show abundant mm-scale pores in the ash matrix (e.g. Fig. 2E, F) (Moore \& Jackson 2020, their fig. 3). Water absorption is high, $16-$ $19 \%$; the water-saturated density, $1.80-2.02 \mathrm{~g} / \mathrm{cm}^{3}$, may approximate the in situ density of the porous sub-seafloor deposits. By contrast, tuff samples at 235.1, 243.4, 271.9 m.b.s. (287.1, 297.2 and 303.8 m measured depth) have higher oven-dried density, $2.05-2.19 \mathrm{~g} / \mathrm{cm}^{3}$ (Jackson et al. 2019a, samples RS27, 28, 32). Thin sections of these samples show a compact ash matrix and a general absence of mmscale pores. Water absorption is lower, $8-12 \%$ and the water-saturated density, $2.21-2.38 \mathrm{~g} / \mathrm{cm}^{3}$, may approximate the in situ density of the more compact sub-seafloor deposits. The coherent basalt at 282.1 m.b.s. (344.7 m measured depth) has $2.38 \mathrm{~g} / \mathrm{cm}^{3}$ oven-dry density, $0.04 \%$ water absorption, and 2.48 $\mathrm{g} / \mathrm{cm}^{3}$ water-saturated density.

\section{Granular and tubular microstructures}

Fine-scale $(5-30 \mu \mathrm{m})$ linear features are preserved in translucent, yellowish-gray zones (5YR 7/2) within the glassy ash and lapilli of many $79 S$ thin sections (Fig. 6). These linear features resemble microtubules thought to record endolithic microborings produced by microbial dissolution and alteration of glass (Fisk et al. 2003, Thorseth et al. 1991, 2001, Walton 2008, Fisk \& McLoughlin 2013). The tubular features are much finer than the thickness of the thin section (Fig. 6E, F). Tiny "hairlike", overlapping protrusions are arranged roughly perpendicular to contacts between fresh and altered 
glass (Fig. 6A-C); these protrusions are similar to tubules described by Fliegel et al. (2012, their fig. 4) in ancient basaltic pillow lavas from DSDP Hole 418A. There are abundant granular features, as well (Thorseth et al. 1991, Furnes et al. 2001, Staudigel et al. 2008) (Fig. 6B, D, L).

In the $79 S 36.4$ m.b.s. sample from the subaerial tuff cone, $70.8{ }^{\circ} \mathrm{C}$ in 1980 (Jakobsson \& Moore 1982), protrusions $<1 \mu \mathrm{m}$ in width and up to 25 $\mu \mathrm{m}$ in length emerge from the contact between translucent, yellowish-gray $(5 \mathrm{Y} 7 / 2)$ glass and opaque, altered glass selvages (Figs. 6A, B, C). They occur on the surfaces of alteration rinds along the perimeter of the lapillus (Figs. 6A, B, C, $a$ ), on accretionary ash particles (Fig. 6A, site $b$ ) and along internal vesicles (Figs. 6A, B, site $c$ ). There are also opaque, olive gray (5Y 3/2) granular features (Fig. $6 \mathrm{~B}$, site $d$ ).

In the submarine $79 S 107.5$ m.b.s. sample, 140.8 ${ }^{\circ} \mathrm{C}$ in 1980 (Jakobsson \& Moore 1982), coarse ashto lapilli-sized particles locally preserve translucent, yellowish-gray (5Y 7/2), apparently fresh glass (Fig. 4G). In one example, irregular linear features $<1 \mu \mathrm{m}$ in width and up to $30 \mu \mathrm{m}$ in length protrude from the altered selvage of an internal vesicle into the yellowish-gray glass (Fig. 6D, site $a$ ). They radiate from the alteration rinds along other internal vesicles (Figs. 6E, F, site $d ; 6 \mathrm{G}$, site $d$ ), as well. The linear features also form in the glass (Fig. 6E, $c$ ), along micro-fractures (Fig. $6 \mathrm{G}, e$ ) and within granular features (Fig. 6D, F, site $b$ ). No vestiges of translucent fresh glass remain in the correlative 100.1 m.b.s., SE-02A $17 S$ thin section, $141.3{ }^{\circ} \mathrm{C}$ in 1980 and $126^{\circ} \mathrm{C}$ in 2017 (Jakobsson \& Moore 1982, Jackson et al. 2019a). Here, dark olive gray (5Y 3/2) opaque zones obscure radially-oriented protrusions up to $20 \mu \mathrm{m}$ in length (Fig. $6 \mathrm{H}$, site $a$ ), granular features (Fig. 6H, site $b$ ), and a possible microcrack (Fig. $6 \mathrm{H}$, site $c$ ). The progressive development of weakly birefringent, nano-crystalline clay mineral in the altered glass conceals the fine-scale features. By contrast, in the 145 m.b.s., SE-02A $17 S$ thin section, $82.5^{\circ} \mathrm{C}$ in 1980 and $100.2{ }^{\circ} \mathrm{C}$ in 2017 (Jakobsson \& Moore 1982, Jackson et al. 2019a), translucent, yellowish-gray, apparently fresh glass persists (Fig. 6I, site $a$ ). Here, the contact of fresh glass with opaque altered glass around internal vesicles is occupied by granular features (Fig. 6I, site $b$ ). Nearby, a shadowy tangle of linear features up to $30 \mu \mathrm{m}$ in length (Fig. 6I, site $c$ ) occurs in the very weakly birefringent, light brown (5YR 5/6) altered glass rind of a vesicle filled with zeolite. These may represent microtubules produced in fresh glass before progressive alteration to authigenic minerals.

In the submarine $79 S$ sample at 168.9 m.b.s., 70.6 ${ }^{\circ} \mathrm{C}$ in 1980 (Jakobsson \& Moore 1982), translucent, yellowish-gray, apparently fresh glass is preserved in coarse ash and lapilli (Fig. 6J, site a). However, opaque, moderate yellow brown (5Y 4/4) selvages and zones make diffuse, irregular boundaries with the fresh glass (Fig. 6J, site $b$ ). Discrete protrusions are not detected at the petrographic scale (Figs. 6K, site $c$; $6 \mathrm{~L}$, site $c$ ), but these do occur in glass lapilli and along micro-fractures at 157.1 m.b.s. (Jackson et al. 2019b). The dissolved perimeters of olivine and plagioclase crystals (Fig. 6L, site $b$ ) also contain traces of granular features. In addition, chambered, opaque rods $1-2 \mu \mathrm{m}$ in width and up to $50 \mu \mathrm{m}$ in length occur in the translucent glass (Fig. 6L, site $d$ ).

\section{DISCUSSION}

Narrow ash rims

At least two processes are known to produce ash rims on glass pyroclasts. Accretionary ash coatings on lapilli commonly form in an eruption column or cloud when ash attaches to a larger particle and then further ash accretes before falling from the cloud onto Earth's surface (Lorenz 1974a, Gilbert \& Lane 1994, Schumacher \& Schmincke 1995, Mueller et al. 2016). These armoured lapilli may be deposited into water; some survive (and some are destroyed). Furthermore, accretionary lapilli that have been deposited on land may be re-deposited into water. Alternatively, enveloping fine ash particles may be produced through in situ granulation of the surfaces of hot juvenile lapilli, caused by thermal stress as the hot pyroclasts briefly travel through water and are quenched during Surtseyan eruptions (Colombier et al. 2019). In addition, it has been hypothesized that landslides and slumps of freshly erupted subaerial deposits during explosive eruptions (Moore 1985, Lorenz et al. 2017) may carry subaerial lapilli with accretionary ash coatings into submarine and sub-seafloor environments; these eruptive and depositional processes remain poorly understood.

Armoured lapilli that formed in an ash-charged atmosphere are common in the Surtur sub-aerial tuff cone deposits (Fig. 4A, B). They have been described and mapped by Lorenz (1974b) and are recorded in the SE-01 (Jakobsson \& Moore 1982, their fig. 
8) and the SE-02B drill cores (McPhie et al. 2020, their figs. $4 \mathrm{~d}, 6 \mathrm{c})$. By contrast, the narrow ash rims that outline the outer surfaces of glass particles in some submarine (Figs. 2A-C) and sub-seafloor tuff deposits (Figs. D-H) show variations in thickness, composition, particle sizes and shapes that differ from the altered vitric ash matrix. These features appear to record diverse depositional processes. For example, in lapilli tuff at 170.6 m.b.s. dark gray (N2) ash rims cover sub-rounded clots of altered vitric ash (Fig. 2C); the clast composed of the agglomerated clots is also rimmed with dark gray ash. The origins of these rims remain unknown. By contrast, at the approximate depth of the pre-eruptive seafloor, 180.5 m.b.s., a narrow rim of angular olive brown (5Y $5 / 6-5 \mathrm{Y} 4 / 4)$ fragments resembles the enveloping ash that may be produced by in situ granulation as a hot juvenile pyroclast travels though water and is quenched (Fig. 2D) (Colombier et al. 2019). Similar fractured lapilli with jigsaw cracks in submarine 79SA samples have been described by Jackson et al. (2019b). At 212.03 and 218.86 m.b.s., ash rims adhere to the surfaces of altered vesicular glass fragments; the rims are composed of dense, homogeneous fine ash (Fig. 2E) and poorly sorted, sub-angular ash (Fig. 2F). Large, nearly contiguous pores $1-3 \mathrm{~mm}$ in length, now partially filled with mineral cements, surround these features and follow the intergranular outlines of the narrow ash rims. It has been suggested that these clasts and vesicles could represent freshly erupted tephra from subaerial deposits that were remobilized by submarine landslides and slumps, which incorporated steam and atmospheric gases (Lorenz 1974a, 1986, Moore 1985). However, the forms of the ash rims differ from the thicker, rounded surface coatings of typical armoured lapilli. The origins of these complex features thus remain unclear.

\section{Glass alteration}

The original thin sections from the 1979 drill core (79S) preserve translucent, yellowish-gray (5Y 7/2) glass in all hydrothermal and structural zones traversed by the SE-01 borehole (Figs. 1, 4 , Table 1), although this glass is very rare in the high temperature hydrothermal zone at $85-115$ m.b.s. By contrast, the thin sections from the 2917 drill cores (17S) preserve little yellowishgray $(5 \mathrm{Y} 7 / 2)$ glass and palagonitized glass rinds are thicker and more birefringent that those of the $79 S$ thin sections at parallel depths. This difference indicates that substantial alteration occurred during the intervening 38 years of hydrothermal alteration at diverse temperatures and fluid compositions in the volcano. The average density of the oven-dried lapilli tuff increased slightly from 1979 to 2017 (Fig. 5) probably through the growth of mineral cements in the vesicles of glass fragments and the ash matrix of the tuff (Fig. 4).

The moderate yellow (5Y 6/6) and olive brown (5Y 5/6 - 5Y 4/4) colours of palagonitized glass rinds in the $79 S$ thin sections (Fig. 4A, G, M, Table 1) are preserved in some $17 S$ thin sections, especially in samples from the submarine lapilli tuff (Fig. 4I, O, Table 1). In $79 S$ thin sections from the subaerial tuff cone and the submarine inflow zone, however, some palagonitized glass rinds have an unusual moderate to dark greenish yellow (10Y 6/6 - 10Y 6/4) colour (Fig. 4A, J, Table 1). This colour has been transformed to dark yellowish orange (10YR 6/6) and light brown (5YR 5/6) in the $17 S$ thin sections. The associated differences in authigenic mineral assemblages are not yet known.

Marked differences also exist in altered glass of the $79 \mathrm{~S}$ and 79SA thin sections. Altered glass rinds in the 79SA thin sections are more orange (Fig. 4E), more brown (Fig. 4K, N), and more birefringent (Fig. 4H) than those of the original $79 S$ thin sections at similar depths (Table 1). The unusual moderate to dark greenish yellow of altered glass in the $79 S$ thin sections from the subaerial tuff cone (sample 79S-37.0 $\mathrm{m})$ and submarine inflow zone (sample $79 S-147.7 \mathrm{~m}$ ) (Fig. 4A, J) is dull olive brown (5Y 4/4) and olive gray $(5 \mathrm{Y} 3 / 2)$ in the $79 S A$ thin sections (Fig. $4 \mathrm{~B}, \mathrm{~K}$, Table 1). The moderate greenish yellow (5Y 6/6) and olive brown $(5 \mathrm{Y} 4 / 4)$ of altered glass rinds in $79 S$ thin sections from the upper submarine lapilli tuff (Fig. 4E) are pale yellowish orange (10YR 8/6) and light brown (5YR 5/6) in the equivalent 79SA thin section (Fig. 4D). The rare yellowish-gray glass of lapilli in the $79 S$ thin section from the high temperature hydrothermal zone appears as dense, opaque nano-crystalline clay mineral in the equivalent 79SA thin section (Fig. 4G, H); no translucent glass persists. The opaque moderate yellow brown (5Y 4/4) of altered fine ash in the $79 S$ thin section at 168.9 m.b.s. is grayish brown (5YR 3/2) in the 79SA thin section at 170.1 m.b.s. (Fig. 4M, N). Overall, the internal zones of 79SA glass fragments appear less translucent and tend to grayish yellow (5Y 8/4) or dusky yellow (5Y 6/4), as compared with the apparently fresh glass of $79 S$ thin sections (Fig. 4B, E, K, N, Table 1). 
Storage conditions evidently had a pronounced influence on the surface colour of the submarine SE-01drill core, transforming it from grayish-green to yellowish brown over time in the repository environment. The thin section investigations (Figs. 4, 6) indicate that alteration under ambient conditions also influenced the petrographic characteristics of the lapilli tuff. The petrographic studies suggest the oxidation of iron in altered glass rinds (Fig. 4D, E, sites $a, a$ ", Fig. $4 \mathrm{~J}, \mathrm{~K}$, sites $c$, $c$ "), the transformation of fresh glass to nano-crystalline clay mineral (Fig. $4 \mathrm{G}, \mathrm{H}$, sites $b, b$ ") and the possible crystallization of fine-grained, isotropic analcime that lends opacity to the 79SA ash matrix (Fig. 4E, H).

A recent article describes the differences in the petrographic characteristics of the archived 1979 SE01 drill core (79SA) and the 2017 SE-02B drill core $(17 S)$ as a means to estimate time-lapse alteration in the volcano from 1979 to 2017 (Prause et al. 2020). The study provides an important empirical record of alteration processes. The present investigations indicate, however, that the 79SA samples do not provide a clear reference framework for alteration progress uniquely in the volcanic environment because they have undergone considerable change during the 38 years they resided in the core boxes. It also indicates that further sealing of the 2017 cores from atmospheric contamination in order to preserve their true alteration fabrics should be considered.

\section{Possible endolithic microborings}

Fine-scale microtubules similar to those inferred to be endolithic microborings indicative of microbial activity (Fisk et al. 2003, Staudigel et al. 2008, Walton 2008) occur in the apparently fresh glass of $79 S$ thin sections from the subaerial tuff cone, the $79 S$ and $17 S$ thin sections from the higher temperature hydrothermal zone, and the $17 S$ thin sections from the submarine inflow zone and the deeper submarine deposits (Fig. 6). Traces of microtubular structures along the surfaces of glass vesicles and microcracks also occur in a 79SA thin section at 157.1 m.b.s. (Jackson et al. 2019b). The overall diameter of the tubules is remarkably constant, $<1$ micron, whereas lengths show considerable variation. Generally, the tubules are straight or gently curved and they are usually of a constant length at a given site, $10 \mu \mathrm{m}$ in some locations and $20 \mu \mathrm{m}$ in others. The tubules mainly have a constant diameter, do not pinch and swell, and are not sharp at the tip but, instead, maintain diameter out to a blunt end. They protrude into apparently fresh glass and are packed together side-by-side where they emerge on the contact of fresh glass with the altered glass rind of a glass particle or the inner wall of a vesicle or a microcrack surface.

Microbiological analyses of fluids extracted from the SE-01 borehole in 2009 indicate traces of potentially indigenous thermophilic bacteria and archaea at 145 m.b.s. and 174 m.b.s. (Marteinsson et al. 2015). These studies suggest the possibility that some alteration could have occurred through biotic activity deep in the submarine lapilli tuff deposits of Surtsey. The tubular features suggestive of possible endolithic microborings are especially well-developed in a lapillus with apparently fresh glass in a $79 S$ thin section at 107.5 m.b.s. (Figs. 4G, 6D-G). There, the growth rate of microtubule lengths is about $2 \mu \mathrm{m} / \mathrm{yr}$ (30 $\mu \mathrm{m}$ since 1964). This rate is far more rapid than rates predicted by Staudigel et al. (2008) for tubular bioalteration in soils, which requires $>1000$ years to initiate. The borehole temperature measured at 107.5 m.b.s. in $1980,140.8{ }^{\circ} \mathrm{C}$ (Jakobsson \& Moore 1982), exceeded an inferred limit for functional microbial life, $120{ }^{\circ} \mathrm{C}$ (Ivarsson et al. 2015, Kashefi \& Lovley 2003, Prieur \& Marteinsson 1998). It is possible that an early low-temperature episode of functional microbial activity could have persisted for a few years before progressive heating produced the $141^{\circ} \mathrm{C}$ temperature maximum measured in 1980 (Jakobsson \& Moore 1982), which had decreased to $126{ }^{\circ} \mathrm{C}$ in 2017 (Jackson et al. 2019a).

\section{CONCLUSIONS}

Petrographic studies of thin sections from the 1979 and 2017 Surtsey drill cores describe narrow ash rims on coarse ash- to lapilli-sized basaltic glass pyroclasts in subaerial, submarine, and sub-seafloor lapilli tuff (Fig. 2), the progression of glass alteration in diverse environments from 1979 to 2017 (Fig. 4), and the characteristics of tubular microstructures in apparently fresh glass (Fig. 6). The origins of the narrow ash rims that outline altered glass pyroclasts in submarine and sub-seafloor deposits remain unclear. Some rims may record in situ granulation by thermal stress during submarine eruption. Other rims record alteration and/or depositional processes in the submarine and sub-seafloor environments that are poorly understood. In porous lapilli tuff $70-80 \mathrm{~m}$ below the pre-eruption seafloor, altered 
glass fragments with narrow rims of fine ash are surrounded by large, irregularly-shaped cavities that may be filled with mineral cements (Fig. 2EF). These samples have low oven-dry density, $1.4-$ $1.6 \mathrm{gr} / \mathrm{cm}^{3}$ and high water absorption, $19-21 \mathrm{wt} \%$ (Fig. 5) (Jackson et al. 2019a, their table S1). Nearby samples, however, have a compact ash matrix with few vesicular cavities; they have higher dry density, $2.13-2.19 \mathrm{gr} / \mathrm{cm}^{3}$ and low water absorption, $8-9 \mathrm{wt}$ $\%$. These differences produce a heterogeneous fabric in the submarine and sub-seafloor deposits.

Comparisons of the petrographic characteristics of glass fragments in the original thin sections of the 1979 drill core (79S) and the thin sections of the 2017 drill cores $(17 S)$ at corresponding depths indicate that alteration has progressed rapidly in all structural and hydrothermal environments over the past 38 years (Fig. 4, Table 1). Microtubules and narrow protrusions along contacts between fresh and altered glass are common in the apparently fresh glass of $79 S$ thin sections (Fig. 6). These features resemble endolithic microborings but further analyses are needed to determine possible traces of microbial activity. The microtubules have become obscured by progressive glass alteration in the $17 \mathrm{~S}$ thin sections (Fig. 6H, I).

The marked differences in the petrographic characteristics of the altered glass in the $79 S$ thin sections and the 79SA thin sections, prepared after 38 years of archival storage (Fig. 4, Table 1), are verified through precise correlations with Munsell colours in plane polarized light and isotropic and birefringent characteristics (Table 1). The present investigations indicate that Surtsey glass remains labile at ambient temperatures and atmospheric conditions. This reactive propensity suggests that the 2017 cores may also evolve in the repository environment. The colours and fabrics of fresh and altered glass preserved in the original thin sections of the 1979 drill core (79S) therefore provide a critical reference for establishing past and future rates of alteration in the volcano (Figs. 4,6 ). Measurements of rock material characteristics were made immediately post-drilling in 1979 and 2017 (Fig. 5) and so provide an accurate reference for changes in physical properties produced uniquely in the volcanic environment. Although many 2017 core sections are stored in nitrogen gas or under refrigeration, additional conservation efforts should be put into place and a reference suite of glass-covered thin sections prepared for the future core archive.

\section{ACKNOWLEDGEMENTS}

Funding for the SUSTAIN project was provided by the International Continental Scientific Drilling Program (ICDP); a grant of excellence from the Icelandic Research Fund, ICF-RANNÍS; the Bergen Research Foundation and K.G. Jebsen Centre for Deep Sea Research at the University of Bergen, Norway; the German Research Foundation (DFG); and DiSTAR, Federico II, University of Naples, Federico II, Italy. The University of Utah, USA, and the Icelandic power companies, Reykjavík Energy and Landsvirkjun, contributed additional funds. The logistical support organized by M. T. Gudmundsson and provided by the Icelandic Coast Guard was instrumental in carrying out the drilling operation. I gratefully acknowledge S. P. Jakobsson and J. G. Moore for their contributions to drilling on Surtsey, and the 2017 DOSECC drilling team led by B. Marshall with drillers S. Cole, J. Blouin, A. J. Vecchiarelli, M. Lyon, and M. Vinson along with all members of the science and technical teams for their contributions to the SUSTAIN project. K. Jónasson maintains the Surtsey drill core archive at the Iceland Institute of Natural History. Figure 1 was drafted by B. Black. J. Fisher contributed to measurements of material properties and high resolution scans of reference sample thin sections. The article has benefitted from reviews by J. McPhie, J. G. Moore, K. Jónasson and M. Ivarsson.

\section{REFERENCES}

Alexandersson, T., 1970. The sedimentary xenoliths from Surtsey: marine sediments lithified on the sea floor. Surtsey Research Progress Report 6, 101-116.

Alexandersson, T., 1972. The sedimentary xenoliths from Surtsey: turbidites indicating shelf growth. Surtsey Research Bulletin 5, $83-89$.

ASTM C97/C97M-18, 2018. Standard Test Methods for Absorption and Bulk Specific Gravity of Dimension Stone, ASTM International, West Conshohocken, PA.

DOI: https://doi.org/10.1520/C0097_C0097M-18.

Baldursson, S. \& Á. Ingadóttir, 2007. Nomination of Surtsey for the UNESCO World Heritage List, Icelandic Institute of Natural History, Reykjavik.

Colombier, M., B. Scheu, U. Kueppers, S. J. Cronin, S. B. Mueller, F. B. Wadsworth, M. Tost, K. J. Dobson, B. Ruthensteiner \& D. B. Dingwell, 2019. In situ granulation by thermal stress during subaqueous volcanic eruptions. Geology 47, 1-4.

Fisk, M. R. \& N. McLoughlin, 2013. Atlas of alteration textures in volcanic glass from the ocean basins. Geosphere 39 (2), 317-341. 
Fisk, M. R., M. C. Storrie-Lombardi, S. Douglas, R. Popa \& C. Di Meo-Savoie, 2003. Evidence of biological activity in Hawaiian sub-surface basalts. Geochemistry Geophysics Geosystems 4 (12).

DOI: https://doi.org/10.1029/2002GC000387.

Fliegel, D., E. Knowles, R. Wirth, A. Templeton, H. Staudigel, K. Muehlenbachs \& H. Furnes, 2012. Characterization of alteration textures in Cretaceous oceanic crust (pillow lava) from the N-Atlantic (DSDP Hole 418A) by spatially-resolved spectroscopy. Geochimica and Cosmochimica Acta 96, 80-93.

Furnes, H., H. Staudigel, I. H. Thorseth, T. Torsvik, K. Muehlenbachs \& O. Tumyr, 2001. Bioalteration of basaltic glass in the oceanic crust. Geochemistry Geophysics Geosystems, 2 (8).

DOI: https://doi.org/10.1029/2000GC000150.

Gilbert, J. S. \& S. J. Lane, 1994. The origin of accretionary lapilli. Bulletin of Volcanology 56, 398-411.

Ivarsson, M., S. Bengtson, H. Skogby, P. Lazor, C. Broman, V. Belivanova \& F. Marone, 2015. A fungal-prokaryotic consortium at the basalt-zeolite interface in subseafloor. PLoS ONE 10 (10), e0140106.

DOI: https://doi.org/10.1371/journal.pone.0140106

Jackson, M. D., M. T. Gudmundsson, T. B. Weisenberger, J. M. Rhodes, A, Stefánsson, B. I. Kleine, P. C. Lippert, J. M. Marquardt, H. I. Reynolds, J. Kück, V. Th. Marteinsson, P. Vannier, W. Bach, A. Barich, P. Bergsten, J. G. Bryce, P. Cappelletti, S. Couper, M. F. Fahnestock, C. F. Gorny, C. Grimaldi, M. Groh, Á. Gudmundsson, Á. Th. Gunnlaugsson, C. Hamlin, Th. Högnadóttir, K. Jónasson, S. S. Jónsson, S. L. Jørgensen, A. M. Klonowski, B. Marshall, E. Massey, J. McPhie, J. G. Moore, E. S. Ólafsson, S. L. Onstad, V. Perez, S. Prause, S. P. Snorrason, A. Türke, J. D. L. White \& B. Zimanowski, 2019. SUSTAIN drilling at Surtsey volcano, Iceland, tracks hydrothermal and microbiological interactions in basalt 50 years after eruption, Scientific Drilling, 25, 35-46.

DOI: https://doi.org/10.5194/sd-25-35-2019.

Jackson, M. D., S. Couper, C. V. Stan, M. Ivarsson, M. Czabaj, N. Tamura, D. Parkinson, L. M. Miyagi \& J. G. Moore, 2019b. Authigenic mineral textures in submarine 1979 basalt drill core, Surtsey volcano, Iceland. Geochemistry, Geophysics, Geosystems 20 (7).

DOI: https://doi.org/10.1029/2019GC008304.

Jakobsson, S. P. \& J. G. Moore, 1982. The Surtsey Research Drilling Project of 1979. Surtsey Research Progress Report 9, 76-93.

Jakobsson, S. P. \& J. G. Moore, 1986. Hydrothermal minerals and alteration rates of Surtsey volcano, Iceland. Geological Society of America Bulletin 97 (5), 648-659.

Jakobsson, S. P., K. Thors, Á. T. Vésteinsson \& L. Ásbjörnsdóttir, 2009. Some aspects of the seafloor morphology at Surtsey
Volcano: the new multibeam bathymetric survey of 2007. Surtsey Research 12, 9-38.

Kashefi, K. \& D. R. Lovley, 2003. Extending the upper temperature limit for life. Science 301, 934.

Lorenz, V., 1974a. Vesiculated tuffs and associated features. Sedimentology 21, 273-291.

Lorenz, V., 1974b. Study of the Surtsey tephra deposits. Surtsey Research Progress Report 7, 72-79.

Lorenz, V., 1986. On the growth of maars and diatremes and its relevance to the formation of tuff rings. Bulletin of Volcanology $48,265-274$.

Lorenz, V., S. Suhr \& P. Suhr, 2017. Phreatomagmatic maardiatreme volcanoes and their incremental growth: A model. In Németh, K., G. Carrasco-Nuñez, J. J. Aranda-Gómez \& , I. E. M. Smith (eds), Monogenetic Volcanism. Geological Society, London, Special Publications, 446.

DOI: http://doi.org/10.1144/SP446.4

Marteinsson, V., A. Klonowski, E. Reynisson, P. Vannier, B. D. Sigurdsson \& M. Ólafsson, 2015. Microbial colonization in diverse surface soil types in Surtsey and diversity analysis of its subsurface microbiota. Biogeosciences 12, 1191-1203.

Moore, J. G., 1985. Structure and eruptive mechanism at Surtsey Volcano, Iceland. Geological Magazine 122, 649-661.

McPhie, J., J. D. L. White, C. Gorny, M. D. Jackson, M. T. Gudmundsson \& S. Couper, 2020. Lithofacies from the 19631967 Surtsey eruption in SUSTAIN drill cores SE-2a, SE-2b and SE-03. Surtsey Research 14, 19-32.

Moore, J. G. \& M. D. Jackson, 2020. Observations on the structure of Surtsey. Surtsey Research 14, 33-45.

Mueller, S. B., U. Kueppers, P. M. Ayris, M. Jacob \& D. B. Dingwell, 2016. Experimental volcanic ash aggregation: Internal structuring of accretionary lapilli and the role of liquid bonding. Earth and Planetary Science Letters 433, $232-240$

Oddson, B., 1982. Rock quality designation and drilling rate correlated with lithology and degree of alteration in volcanic rocks from the Surtsey 1979 drill hole. Surtsey Research Progress Reports 9, 94-97.

Prause, S., T. B. Weisenberger, P. Cappelletti, C. Grimaldi, C. Rispoli, K. Jónasson, M. D. Jackson \& M. T. Gudmundsson, 2020. Alteration progress within the Surtsey hydrothermal system, SW Iceland - a time-lapse alteration study of cores drilled in 1979 and 2017. Journal of Volcanology and Geothermal Research 392, 106754.

Prieur, D. \& V. Th. Marteinsson, 1998. Prokaryotes living under elevated hydrostatic pressure. Advances in Biochemical Engineering / Biotechnology 61, 23-35.

Reynisson, R. F. \& Jakobsson, S. P., 2009. Xenoliths of exotic origin at Surtsey volcano, Iceland. Surtsey Research Bulletin 12, 21-27. 
Schipper, C. I., S. P. Jakobsson, J. D. L. White, J. M. Palin \& T. Bush-Marcinowski, 2015. The Surtsey magma series. Scientific Reports 5, 11498. DOI: $10.1038 /$ srep11498.

Schumacher, R. \& H.-U. Schmincke, 1995. Models for the origin of accretionary lapilli. Bulletin of Volcanology 56 (8), 626-639. Staudigel, H., H. Furnes, N. McLoughlin, N. R. Banerjee, L. B. Connell \& A. Templeton, 2008. 3.5 billion years of glass bioalteration: Volcanic rocks as a basis for microbial life? Earth Sciences Reviews 89, 156-176.

Thorseth, I. H., H. Furnes \& O. Tumyr, 1991. A textural and chemical study of Icelandic palagonite of varied composition and its bearing on the mechanism of the glass-palagonite transformation, Geochimica and Cosmochimica Acta 55, 731-749.

Thorseth, I. H., T. Torsvik, V. Torsvik, F. L. Daae \& R. B. Pedersen, 2001. Diversity of life in ocean floor basalt. Earth and Planetary Science Letters 194 (1-2), 31-37.

DOI: https://doi.org/10.1016/S0012-821X (01)00537-4

Thórarinsson, S., 1965. The Surtsey eruption, course of events and the development of the new island. Surtsey Research Progress Report 1, 52-59.

Thórarinsson, S., 1967. Surtsey, The New Island in the North Atlantic. The Viking Press, New York.

Thórarinsson, S., Th. Einarsson, G. Sigvaldason \& G. Elísson, 1964. The submarine eruption off the Vestmann Islands 196364. Bulletin of Volcanology 29, 435-455.

Türke, A., M. D. Jackson, W. Bach, W.-A. Kahl, B. Grzybowski, B. Marshall, M. T. Gudmundsson \& S. L. Jørgensen, 2019. Design of the subsurface observatory at Surtsey Volcano, Iceland. Scientific Drilling 25, 57-62. DOI: https://doi.org/10.5194/sd-25-57-2019

Walton, A. W., 2008. Microtubules in basalt glass from Hawaii Scientific Drilling Project \#2 phase 1 core and Hilina slope, Hawaii: evidence of the occurrence and behavior of endolithic microorganisms. Geobiology 6, 351-364.

Weisenberger, T. B., M. T. Gudmundsson, M. D. Jackson, C. F. Gorny, A. Türke, B. I. Kleine, B. Marshall, S. L. Jørgensen, V. Th. Marteinsson, A. Stefánsson, J. D. L. White, A. Barich, P. Bergsten, J. G. Bryce, S. Couper, M. F. Fahnestock, H. Franzson, C. Grimaldi, M. Groh, Á. Gudmundsson, Á. Th. Gunnlaugsson, C. Hamelin, Th. Högnadóttir, K. Jónasson, S. S. Jónsson, A. Klonowski, J. Kück, R. L. Magnússon, E. Massey, J. McPhie, E. S. Ólafsson, S. L. Onstad, S. Prause, V. Perez, Velveth, J. M. Rhodes \& S. P. Snorrason, 2019. Operational Report for the 2017 Surtsey Underwater volcanic System for Thermophiles, Alteration processes and INnovative concretes (SUSTAIN) drilling project at Surtsey Volcano, Iceland: GFZ German Research Centre for Geosciences.

DOI: http://doi.org/10.2312/ICDP.5059.001 


\title{
Erosion and sedimentation in Surtsey island quantified from new DEMs
}

\author{
BIRGIR VILHELM ÓSKARSSON ${ }^{1}$, KRISTJÁN JÓNASSON ${ }^{1}$, \\ GUĐMUNDUR VALSSON ${ }^{2}$ AND JOAQUÍN M. C. BELART ${ }^{2,3}$ \\ ${ }^{1}$ Icelandic Institute of Natural History, Urriðaholtsstræti 6-8, 210 Garðabær, birgir@ni.is (corresponding author). \\ ${ }^{2}$ National Land Survey of Iceland, Stillholt 16-18, 300 Akranes. \\ ${ }^{3}$ Institute of Earth Sciences, University of Iceland, Sturlugata 7 - Askja, 101 Reykjavík.
}

\begin{abstract}
We present data from a photogrammetric study on Surtsey island that generated three new DEMs and orthoimages, two from scanned aerial images from 1967 and 1974 and one from high-resolution closerange images from a survey in 2019. DEM differencing allowed for quantification of the erosion and the sedimentation in the island since 1967. Of the subaerial volcanics, about $45 \%$ of the lava fields have eroded away but only about $16 \%$ of the tuff cones. The prevailing SW coastal wave erosion is evident from the erosive pattern in Surtsey, and the cumulative loss of the coastal margins amounts to $28 \pm 0.9 \times 10^{6} \mathrm{~m}^{3}$ since 1967 , with the current average erosion rate of $0.4 \pm 0.02 \times 10^{6} \mathrm{~m}^{3} / \mathrm{yr}$. Wind deflation and runoff erode the tuff cones and the sediments at the flanks of the cones, with the total volume loss amounting to $1.6 \pm 0.2 \times 10^{6} \mathrm{~m}^{3}$ and the current erosion rate of $0.03 \pm 0.004 \times 10^{6} \mathrm{~m}^{3} / \mathrm{yr}$. A rapid decline in erosion rates characterized the first years post-eruption, and the coastal erosion rate during the winter of 1967-68 was about 5-6 times higher than the current erosion rate due to the thinner and less cohesive nature of the lava apron at the edge of the shelf. The cones eroded at a rate about 2-3 times higher during the first years due to the uncompacted and unconsolidated nature of the cones at that time. The 2019 area of $1.2 \mathrm{~km}^{2}$ and an extrapolation of the current erosion rate fits well with the projected erosion curve of Jakobsson et al. (2000) with the island becoming a tuff crag after approximately 100 years.
\end{abstract}

\section{INTRODUCTION}

Since the emergence of Surtsey island from the sea on November $14^{\text {th }} 1963$, researchers have monitored the island from air, sea and land; systematically documenting its growth during the eruption and its rapid post-eruption erosion (e.g. Einarsson 1965, Thorarinsson 1964, 1966, 1968, Norrman 1970, 1978, 1985, Jakobsson \& Gudmundsson 2003, Jakobsson et al. 2009, Romagnoli \& Jakobsson 2015). During the early stages of Surtsey, the active involvement of seawater with the erupting basalts in the relatively shallow subaqueous environment (130 m depth), generated high energy phreatomagmatic eruptions, the eruption becoming a "type" in the international classification scheme for explosive eruptions known as "Surtseyjan eruption" (Walker 1973). The eruption formed two crescent shaped tephra cones and the primary constituents were intercalated layers of fine and coarse-grained tephra, lithics, accretionary lapilli and fusiform bombs (e.g. Lorenz 1974, Norrman 1974). The non-cohesive tephra, saturated with water, was easily eroded by the waves and washed away with the swash. Two adjacent syneruptions, Syrtlingur and Jólnir, formed ephemeral islands that eroded completely within months and a 
third eruption, Surtla, only formed a seamount (e.g. Thorarinsson 1964, 1966, 1968). With the isolation of the vent area in Surtsey from the sea around April 1964, and the transition to effusive volcanism, two half lava shields formed, one in the Surtungur cone from April 1964 to May 1965 and the other in the Surtur cone from August 1966 to June 1967. Lava entering the sea built a delta of foreset breccia and quenched vitric fragments (Thorarinsson 1968, Kjartansson 1966). Subaerial lava flows that were emplaced on top of the delta extended the coastline to the south and eventually protected the cones from the strong coastal erosion and allowed the tephra to palagonitize and consolidate into tuff. The process of palagonitization turned out to be surprisingly fast and in 10 years about $64 \%$ of the total tephra had already palagonitized, significantly increasing the resistance of the cones to erosion (Jakobsson 1972, 1978).

Despite the lava fields to the south shielding the cones, erosion progresses at a remarkably high rate and in 2019 the maximum coastal retreat reached 720 $\mathrm{m}$ and the total area lost because of erosion since 1965 accumulated to $1.8 \mathrm{~km}^{2}$ (e.g. Norrman 1970, 1978, 1985, Jakobsson et al. 2009). The steep submarine slope of Surtsey volcano and its location at the outer margin of the Iceland shelf create conditions for high energy waves to converge and break full-force on the island (Norrman 1970, 1978). Moreover, strong submarine currents circle the island and wave erosion extends down to depths of $>50 \mathrm{~m}$ as seen in the eroded mounds of Jólnir, Syrtlingur and Surtla (Normann 1970, Jakobsson et al. 2009). Extreme erosion was observed in the first years, notably during the winter of 1967-1968, when the southeastern lava apron retreated by up to $140 \mathrm{~m}$ (Norrman 1970). Before that year or since 1965, the lava field of Surtungur had already retreated by about $150 \mathrm{~m}$ (Thorarinsson 1968). The structure of the lava flows, with closespaced (cm to 1-2 m) vertical and subvertical polygonal joints, makes them susceptible to brittle fracturing and failure under stress. The eroded lava cliffs collapse in large blocks, the talus is grinded by the swash and the boulders are heavily polished and rounded in a matter of days (Thorarinsson 1966). Boulders, gravel and sand are then transported and graded along the shores to a spit north of the island (Thorarinsson 1966, Norrman 1970, Calles et al. 1982), the supply decreasing in recent years leading to a recession of the spit. Erosion of the west coast has led to a steepening of the western side of the tuff cone, the cliff developing a notch with overhanging scarps. Moreover, wind erosion is intense and storms with hurricane force are frequent (Petersen \& Jónsson 2020). With compaction, alteration and subsequent palagonitization of the cones, the erosion rate has decreased, but by 1980 the cones had in localized areas lowered by 1.5-2 m (Ingólfsson 1982) and by up to $4 \mathrm{~m}$ in 2004 (Baldursson \& Ingadóttir 2007). Windblown tephra accumulates in natural traps within the lava fields and around the cones, parts of this tephra originating from the eruptions of Jólnir and Syrtlingur (Thorarinsson 1968). Runoff from seasonal rain erodes rills and gullies in the unconsolidated tephra and sediments. Slumps, mudflows and solifluction mobilize the tephra on the slopes of the cones that accumulate in taluses (Norrman 1970, Calles et al. 1982, Ingólfsson 1982).

Despite the numerous studies documenting the geomorphic change in Surtsey, only minor reference is to the volumetric quantification (e.g. for coastal erosion in Norrman 1970). The total volumetric change was estimated from topographic maps and scanning airborne laser altimetry showing a volumetric decrease of about 25\% from 1968 to 1998 (Garvin et al. 2000). Nevertheless, quantification of the total material loss by erosion and the sediments deposited or redeposited on the island is lacking.

Photogrammetry techniques allow for the generation of high-quality digital elevation models (DEMs) from overlapping nadir and oblique photographs, including from scanned aerial images (e.g. Pedersen et al. 2018, Belart et al. 2019), and nowadays image acquisition with unmanned aerial vehicles (UAVs) is a rapid and cost-effective way to monitor natural environments. Geodetic techniques allow measurements with centimeter precision and geolocation of points in the images yield precise 3D models.

This article presents data processed with digital photogrammetric techniques generating a highresolution DEM for 2019 in addition to two DEMs, one for 1967, the year the eruption ceased, and one for 1974, when the tephra cones had become largely palagonitized and denudation rate had declined significantly. Available is a rich archive of quality photosets with good overlap that can be used to generate DEMs for past years (Landmælingar Íslands 2020, Loftmyndir ehf 2020). Differencing these models yields an overall quantification of the elevation and volume changes since 1967 . In addition, 
we present field observations from a survey in 2019 that aid in the interpretation of the photogrammetric data. Although the comparison in this study is limited to three DEMs, we will here describe the methods and set the stage for future studies quantifying in higher temporal resolution the geomorphic changes in Surtsey.

\section{The Surtsey volcano}

Surtsey is a volcanic island located about $30 \mathrm{~km}$ from the south coast of Iceland and a part of the Vestmannaeyjar archipelago. The eruption of Surtsey began in 1963 and was active intermittently for a period of 3.5 years, terminating in mid-1967 (Einarsson 1965, Thorarinsson 1964, 1966, 1968). The eruption formed a submarine ridge, about 5.8 $\mathrm{km}$ long trending SW-NE, that fed four long-lived eruptions, three of which formed islands and one a seamount. Only Surtsey remains as an island. The Surtsey volcano, with two vents, formed two tephra cones in phreatomagmatic eruptions and two half lava shields in effusive eruptions, with a total area of $2.7 \mathrm{~km}^{2}$. The total volume of Surtsey volcano was estimated to be about $1.1-1.2 \mathrm{~km}^{3}$ of which
$70 \%$ was tephra and 30\% lava (Thorarinsson 1968). The subaerial volume of the island at the end of the eruption in 1967 was estimated to be about 0.1 $\mathrm{km}^{3}$ and the highest point of the island $173 \mathrm{~m}$ a.s.l. (Thorarinsson 1968, Jakobsson et al. 2000). In total, lava comprised about $0.3-0.4 \mathrm{~km}^{3}$ of the total erupted volume, including the submarine foreset breccia but of this volume, only about $0.07 \mathrm{~km}^{3}$ was estimated to be subaerial (Thordarson 2000). The tephra comprised about $0.7-0.8 \mathrm{~km}^{3}$ of which only 0.04 $0.05 \mathrm{~km}^{3}$ was subaerial.

\section{METHODS}

Surtsey was visited in July 18-22, 2019 in the yearly monitoring expedition led by the Icelandic Institute of Natural History. A geodetic survey measured ten ground control points (GCPs) marked with targets (Fig. 1A, label Flagg) along with ten other nearby natural points (Flagg_ex, Nat1), an old benchmark (626, Fig. 1B) and the center of the helipad (THP_C_f). The location of the GCPs are shown in Fig. 2B and the coordinates and labels given in Table 1. The benchmark SURS (Fig. 2B, Sturkell et al. 2009) was occupied with a Trimble NetR5

Table 1. GPS coordinates of ground control points, and their numbers, labels and reference stations. The height $\mathrm{h}$ and $\mathrm{H}$ are in meters, $\mathrm{h}$ is in an ellipsoidal geodetic reference system and $\mathrm{H}$ in a vertical reference system.

\begin{tabular}{|c|c|c|c|c|c|}
\hline Nr. & GCP'S & Lat & Lon & h (GRS80) & H (ISH2004) \\
\hline 1 & 626 & $63^{\circ} 18^{\prime} 00.69806^{\prime \prime}$ & $-20^{\circ} 36^{\prime} 38.08563^{\prime \prime}$ & 118,67 & 53,89 \\
\hline 2 & Flagg1 & $63^{\circ} 18^{\prime} 07.60633^{\prime \prime}$ & $-20^{\circ} 36^{\prime} 48.81971^{\prime \prime}$ & 142,94 & 78,17 \\
\hline 3 & Flagg1_ex & $63^{\circ} 18^{\prime} 07.37060^{\prime \prime}$ & $-20^{\circ} 36^{\prime} 48.98645^{\prime \prime}$ & 141,76 & 76,98 \\
\hline 4 & Flagg2 & $63^{\circ} 18^{\prime} 14.19832^{\prime \prime}$ & $-20^{\circ} 36^{\prime} 55.43431^{\prime \prime}$ & 159,24 & 94,46 \\
\hline 5 & Flagg2_ex & $63^{\circ} 18^{\prime} 13.92611^{\prime \prime}$ & $-20^{\circ} 36^{\prime} 55.48831^{\prime \prime}$ & 159,99 & 95,20 \\
\hline 6 & Flagg3 & $63^{\circ} 18^{\prime} 14.67978^{\prime \prime}$ & $-20^{\circ} 36^{\prime} 23.70404^{\prime \prime}$ & 175,48 & 110,70 \\
\hline 7 & Flagg3_ex & $63^{\circ} 18^{\prime} 14.55741^{\prime \prime}$ & $-20^{\circ} 36^{\prime} 23.33110^{\prime \prime}$ & 175,26 & 110,49 \\
\hline 8 & Flagg4 & $63^{\circ} 17^{\prime} 51.17985^{\prime \prime}$ & $-20^{\circ} 35^{\prime} 54.95749^{\prime \prime}$ & 89,10 & 24,33 \\
\hline 9 & Flagg4_ex & $63^{\circ} 17^{\prime} 50.82319^{\prime \prime}$ & $-20^{\circ} 35^{\prime} 53.84254^{\prime \prime}$ & 90,49 & 25,73 \\
\hline 10 & Flagg5 & $63^{\circ} 17^{\prime} 48.80348^{\prime \prime}$ & $-20^{\circ} 36^{\prime} 18.18708^{\prime \prime}$ & 87,44 & 22,68 \\
\hline 11 & Flagg5_ex & $63^{\circ} 17^{\prime} 48.39999^{\prime \prime}$ & $-20^{\circ} 36^{\prime} 17.21318^{\prime \prime}$ & 87,20 & 22,43 \\
\hline 12 & Flagg6 & $63^{\circ} 18^{\prime} 12.82605^{\prime \prime}$ & $-20^{\circ} 35^{\prime} 35.81968^{\prime \prime}$ & 78,00 & 13,23 \\
\hline 13 & Flagg6_ex & $63^{\circ} 18^{\prime} 12.81001^{\prime \prime}$ & $-20^{\circ} 35^{\prime} 35.05744^{\prime \prime}$ & 79,84 & 15,07 \\
\hline 14 & Flagg7 & $63^{\circ} 18^{\prime} 22.59821^{\prime \prime}$ & $-20^{\circ} 35^{\prime} 48.54144^{\prime \prime}$ & 71,21 & 6,43 \\
\hline 15 & Flagg7_ex & $63^{\circ} 18^{\prime} 22.12830^{\prime \prime}$ & $-20^{\circ} 35^{\prime} 47.89453^{\prime \prime}$ & 71,78 & 7,00 \\
\hline 16 & Flagg8 & $63^{\circ} 18^{\prime} 32.00115^{\prime \prime}$ & $-20^{\circ} 35^{\prime} 55.75310^{\prime \prime}$ & 70,28 & 5,50 \\
\hline 17 & Flagg8_ex & $63^{\circ} 18^{\prime} 32.03681^{\prime \prime}$ & $-20^{\circ} 35^{\prime} 55.79452^{\prime \prime}$ & 70,30 & 5,51 \\
\hline 18 & Flagg9 & $63^{\circ} 18^{\prime} 25.15451^{\prime \prime}$ & $-20^{\circ} 36^{\prime} 11.09302^{\prime \prime}$ & 77,33 & 12,55 \\
\hline 19 & Flagg9_ex & $63^{\circ} 18^{\prime} 25.19063^{\prime \prime}$ & $-20^{\circ} 36^{\prime} 11.08543^{\prime \prime}$ & 77,19 & 12,40 \\
\hline 20 & Nat1 & $63^{\circ} 18^{\prime} 11.59753^{\prime \prime}$ & $-20^{\circ} 36^{\prime} 51.60637^{\prime \prime}$ & 156,14 & 91,36 \\
\hline \multirow[t]{2}{*}{21} & THP_C_f & $63^{\circ} 18^{\prime} 01.04796^{\prime \prime}$ & $-20^{\circ} 35^{\prime} 50.81561^{\prime \prime}$ & 98,84 & 34,07 \\
\hline & Reference & Lat & Lon & h (GRS80) & H (ISH2004) \\
\hline 22 & SURS & $63^{\circ} 18^{\prime} 00.79004^{\prime \prime}$ & $-20^{\circ} 36^{\prime} 20.00381^{\prime \prime}$ & 115,10 & 50,33 \\
\hline 23 & VMEY & $63^{\circ} 2537.16530^{\prime \prime}$ & $-20^{\circ} 17^{\prime} 36.81215^{\prime \prime}$ & 135,28 & 70,31 \\
\hline 24 & SELF & $63^{\circ} 5544.33199^{\prime \prime}$ & $-21^{\circ} 01^{\prime} 56.00393^{\prime \prime}$ & 79,97 & 13,94 \\
\hline
\end{tabular}

